\title{
Basın Fotoğraflarında Sanatsal Kaygı / Ölümün ve Şiddetin Kutsanması ve Yüceltilmesi
}

\author{
Onur Dursun*
}

Filiz Y1ld1z $z^{* *}$

\section{$\ddot{O} z e t$}

Buçalışma, sanatın, toplumsal olaylarda bilinci, maktul üzerinden inşa ederek iktidarmekanizmalarını/ failleri gizlediğini, bu mantı̆̆ın haber medyası, sinema, televizyon gibi medya araçlarına da yansıdığını somutlaştırmayı amaçlamıştır. Çalışmada basın fotoğrafçılığının, sinema ve televizyon gibi görsel-işitsel eğlence/sanat yapıtları başta olmak üzere zaman zaman sanat alanının genel ilkeleri doğrultusunda hareket ederek maktulü yücelttiğ $i$, kutsadığg ve böylece de fail olan büyük ideolojileri görünmez kıldiğg tartışılmıştır. Çalışma, World Press Photo'nun ödüllendirdiği fotoğraflar ile Batı heykel, fresk ve resim gibi sanat dalları aracılığıyla ortaya konan ürünleri kıyaslamalı olarak analiz etmiştir ve örnekler ise Rönesans Dönemi'nden seçilmiştir. Çalışmada yargısal örnekleme kullanılarak hem ödüllü fotoğraflar hem de bu fotoğrafların teknik ve anlatım açısından Rönesans Dönemi eserlerindeki benzerleri kıyaslamah olarak irdelenmiştir. Analiz, Hiristiyan-Batı'nın, sanat ile kitlelerin duygusal yanlarına hitap ederek ve rasyonel bilinci baskılayarak denetim mekanizması oluşturduğunu; bu mekanizmanın basın fotoğrafçılığına da yansıdığını, bu alanda ödül-araç mekanizması ekseninde şiddet ve ölüm gibi durumların sanat yoluyla yüceltildiğini/kutsandığını Platon'un sanat yaklaşımı, özellikle sanatın rasyonel akıl üzerindeki etkileri bağlamında ortaya koymayı amaçlamıştır. Çalışmada foto-muhabirinin, sanatçı olup olmadığı irdelenmiş; sanatsal teknikleri kullanarak ölüm ve şiddet üzerinden sermaye biriktiren foto muhabirliği alanı eleştirel olarak sorgulanmıştır.

Anahatar kelimeler: sanat, görselleştirmenin gücü, basin fotoğrafçılı̆̆l, medya, rasyonel ve duygusal akıl

ORCID ID : https:/ / orcid.org/ 0000-0001-9268-0936 / 0000-0002-1206-4314

E-mail : odursun@cu.edu.tr - filizyildiz@cu.edu.tr

DOI: $10.31122 /$ sinefilozofi.802935

Geliș Tarihi - Recieved: 01.08.2020

Kabul Tarihi - Accepted: 01.12.2020 


\title{
Artistic Concern in Press Photos Blessing and Exaltation of Death and Violence
}

\author{
Onur Dursun*
}

Filiz Y1ld1z ${ }^{* *}$

\begin{abstract}
This study attempted to reveal that art hides consciousness, mechanisms of power/agents in social events, and that this logic is also reflected in such media as news media, sinema, television, etc. The study discussed that at times acting in the manner of the general principles, firstly of audiovisual entertainment/works of cinema and television, of art, photo-journalism glorifes and consecrates the victim and by doing this makes great ideologies invisible. The study analyzed comparatively with the photos awarded by World Press Photo and the products presented in the art branches such as Western sculpture, fresco and painting. In compliance with purposeful sampling, sample images were specified from the Renaissance Period. In the study, awarded photographs were examined comparatively with the works of the Renaissance Period in terms of technique and narration. By using Plato's approach of art, especially art influence on emotional reason, the analysis aims to reveal that through the art, Christian-West creates a control mechanism by addressing the emotional sides of masses and suppressing rational consciousness; and that this mechanism is reflected press photography; and that in the field of photo journalism such conditions as violence and death are glorified/blessed due to rewardinginstrumentalisation mechanisms. In sum, it was argued that photojournalist is an artist or not, and by using artistic techniques accumulating capital through death and violence, the consciousness of photojournalism was examined critically.
\end{abstract}

Key words: art, press photography, power of visualisation, media, rational and emotional reason

ORCID ID : https:/ / orcid.org/ 0000-0001-9268-0936 / 0000-0002-1206-4314

E-mail :odursun@cu.edu.tr - filizyildiz@cu.edu.tr

DOI: $10.31122 /$ sinefilozofi.802935

Geliş Tarihi - Recieved: 01.08.2020

Kabul Tarihi - Accepted: 01.12.2020 


\section{Giriş}

Sanat, toplumların tarihsel gelişiminde önemli bir yere sahiptir. İlk çağlardan günümüze kadar uzanan bir alan olarak sanat, çeşitli amaçlar için kullanılabilmiştir. Sanat, toplumsal yapının değerlerini üretmede, doktrin oluşturma ve yaymada ve kitlelere kabul ettirmede her zaman önemli olmuştur. Özellikle Hıristiyan-Batı, dini ritüeli devam ettirmek ve toplumsal alanda pekiştirmek için sanata başvurmuştur. Rönesans dönemi sanat eserleri, özellikle İsa' nın hikayesini ve acısını kitleler düzeyinde canlı tutmak amacıyla sanattan yararlanmıştır. Tarihsel süreçte sanatın aracı ve içeriği değişse de işlevlerinden birisi bilinçli ya da bilinçsiz olarak aynı kalmıştır: Egemen bilinci ya da bakış açısını kitlelere sunmak.

Tarihin, güç mücadelesi, sanat/görsel sanatların ise bu güç mücadelesinin temsili sunumu üzerine kurulduğu söylenebilir. Hegel, tarihi, "barbar Tin" in mücadelelerle kendini uygarlaştırdığı, özgürleştirdiği ve evrenselleştirdiği bir sahne olarak nitelendirir. İki insanın birbiriyle giriştiği mücadeleyle başlayan ve bilip-tanıma zorunda kalan köle ile biliniptanınma şerefine erişen efendi şeklinde bir bölünmeyle sonuçlanan ve zamanla da uygarlaşan bir bilincin tarihidir (Hegel, 2003; Kojeve, 2015: 79-102). Hegel'in temel metinlerinden seçmelerle oluşturduğu Seçilmiş Parçalar adlı çeviri eserde Nejat Bozkurt, Hegel'de "Tin"in tekil bir kişilik olmadığını, tarihsel süre içinde kendisini aşarak bir kültür evreninde açığa kavuştuğunu, yani devlet, sanat, din ve felsefe gibi varlıkların bütünleştiği bir ortamda kendi anlamına, bütünlügüüne ulaştığını söyler. Tin' in "Öznel Tin", "Nesnel Tin" ve "Saltık Tin" gibi üçlü bir evre sonucunda kendi bütünlüğüne eriştiğini düşünen Hegel, "Tin"in, "Öznel" aşamada eksik bir kavram konumunda iken, "Nesnel" aşamada kültür evrenine kavuştuğu, "Saltık" aşamada ise kendi birlik ve bütünlüğüne ulaştığ vardı̆̆ı kanısındadır. "Tin, "Nesnel" evrede kendi özüne uygun bir varlık alanı olușturmus, özgürlügüüne kavuşmuş ve toplum, devlet ve tarih gibi kültürel kurumlar üretmiştir. "Saltık", yani üçüncü aşamada ise, birlik ve bütünlüğüne ulaşarak, din, sanat ve felsefe gibi varlıklar üretmiştir. Bu üç süreç, tarih boyunca hep birbiriyle etkileşim içinde olmuştur ve bu etkileşim hala da devam etmektedir. Çünkü Hegel'e göre, Tin'in bu üç durumu ölümsüz niteliklidir. Bu üçlü süreç, aslında Hegel'in tez, antitez ve sentez diyalektiğidir. Tezde kendi içene kapanık olan "Tin" özünden dışa doğru, yani doğaya/antiteze doğru atılım yapmıştır. Tin/İde, bu atılımı sürecinde kendi özünden uzaklaşmış, kendine yabancılaşmış ve böylece kendisiyle çelişkili bir duruma düşmüștür. Bu yabancılaşma ve çelişme durumundan kurtulmak içinse yeni bir atılım yapan "Tin", kendi varlığıyla birleştiğ̉i ve çelişkiden kurtulduğu bir kültür dünyası, yani sentez oluşturmuştur (Hegel, 1986: 34-35).

Hegel'in tarih, toplum ve sanata ilişkin düşünceleri, sosyal bilimler yazınını oldukça etkilemiştir. Tarihin, iktidar mücadeleleriyle, kitleleri ve doğayı denetim altına alma çabalarıyla dolu olduğu söylenebilir. Bu mücadeleler ve mücadele yöntemleri, insanın bilincine işlemiştir. Toplumsal varlik olan insan, bilinç olarak, sadece içinde doğduğu ve yetiştiği ailenin değil, aynı zamanda toplumun ve toplumun da bağlı olduğu büyük-küresel ideolojilerin/doktrinlerin bilincini taşımaktadır. Bu bilinç bir dönemlik değil, binlerce yıllık bir tarihin toplamından oluşan bir bilinçtir. Bu, Marks'ın yanlış bilinç olarak ifade ettiği duruma denk düşmektedir. Bireyin, kendine ait olarak bildiği, kendisininmiş gibi davrandığ 1 şeyler aslında kendine ait değildirler; sistematik ideolojilerin parçasıdırlar ve insan bilincine işleyerek insanda bir kendini yanlış bilme durumu yaratmıștırlar. İnsanlar, dünyayı bu pencereden kavramakta ve deneyimlemektedirler. "Platon'un metaforunda bu görünen eyleyiciler kukladır, bu kuklaların ipleri bulunmak zorundadır." (Bourdieu, 2005, 45).

\section{Çalışmanın İzleği}

\section{Amaç}

Bu çalışma, sanatın/görsel sanatların olayları belirli bir çerçeve, bir bakış açısı ekseninde temsile döktükleri, bu süreçte ise belirli kavram setleri kullanarak olayı anlattıkları; aynı ilkelerin kitle iletişim sistemlerine de işlediği düşüncesinden hareket etmiştir. Çalışma, World Press Photo'nun (WPP [Dünya Basın Fotoğrafları Kuruluş]) 1955-2018 yılları arasında ödüllendirdiği fotoğraflara, Rönesans Dönemi'nde bu fotoğraflara içerik olarak denk düşen/ benzeyen, çağrıştıran fresklerin, heykellerin ve resimlerin kıyaslamalı analizine dayanarak yüzlerce yıllık Hıristiyan-Batılı bilincin yansımaları olduğunu Platon'un sanata yaklaşımı bağlamında somutlaştırmayı amaçlamıştır. Fotoğraflara, 'kitlelerin irrasyonel-duygusal yanlarına hitap edilerek yatıştırıldıłıları ve böylece de iktidarın denetimine itildikleri', "maktulün görselleştirilmesiyle failin gizlendiği, yani büyük iktisadi ve siyasi ideolojilerin manipüle edildiği' ve 'maktulün yoksulluğunun ve yoksunluğunun yüceltilerek kutsandığı' 
şeklinde birbiriyle bağlantılı fikirler ekseninde yaklaşılmıștır. Daha da ayrıntılı ifade edecek olursak bu çalışma, kitle iletişim sistemlerinin ve özellikle de haber medyasının, sanatsal kaygılar taşıyarak yarattığı, yaratacağı etik sorunlara, bugün sinema ve televizyon gibi hareketli görüntü tekniğinin ve zaman zaman da içeriğinin üzerine kurulu olduğu fotoğraf, basın fotoğrafçılığı üzerinden açığa çıkarmaya çalışmıştır.

\section{Yöntem ve Örneklem}

Çalışmanın analizi, World Press Photo'nun (WPP [Dünya Basın Fotoğrafları Kuruluş]) 1955-2018 yılları arasında ödüllendirdiği fotoğraflar ile Rönesans Dönemi'nde bu fotoğraflara içerik olarak denk düşen/benzeyen, çağrıştıran fresklerin, heykellerin ve resimlerin kıyaslamasına dayanmaktadır. İncelenen ödüllü fotoğrafları çeken foto-muhabirlerinin, bu fotoğrafları kamusallaştıran medya kuruluşlarının ve aynı şekilde bu fotoğrafları ödüllendiren jüri üyelerinin (yine foto-profesyonelleridir) büyük bir bölümünün Batılı olduğu dikkate alındığında ${ }^{1}$ Hıristiyan-Batılı bilincin, ele aldığ 1 konuları belirli kavram setleri doğrultusunda inşa ettiği düşüncesi oluşmaktadır. Bu düşünceler doğrultusunda yargısal örneklemle seçilen fotoğraflar, Rönesans dönemi eserleriyle karşılaştırmalı olarak nitel-betimsel analize tabi tutulmuştur. Analize ilişkin bilgiler, analiz bölümünde yeri geldiğinde verilmiştir.

\section{Taklit, Gerçekliğin Temsili ve Sıradan Deneyimin Aktarımı Olarak Sanat}

Bugünkü birçok olguyu anlayabilmek için genellikle Antik Yunan'a başvurmak bir geleneğe dönüşmüştür. Bu gelenek, ele alınan konuları daha derinlikli irdeleyibilmek ve günümüzde tartışılan birçok konun, bundan yaklaşık 2500 yıl önce Antik Yunan'da da tartışıldığını görmek açısından önemlidir. Platon, sanat ve sanatçıya ilişkin betimlemelerini Devlet eserinde dile getirmiş, sanatçıyı taklitçi/benzetmeci olarak nitelendirmiştir. Sanatı, gerçeklikten iki adım uzaklaşma (şeylerin yaratıcısı olarak Tanrı; şeylerin yapıcısı olarak zanaatkar; şeylerin taklitçisi olarak sanatçı) olarak değerlendirmiş ve kurgunun tehlikesine dikkat çekmiş (Platon, 2017: 338-339), sanatçıya mesafeli bir duruş sergilemiş ve hatta sansür önerisinde bulunarak, sanatçıyı kurduğu devletine sokmak istememiştir. Bu bakış açısı tıpkı demokrasiye olan güvensizliği ya da toplumsal sınıf ayrımını meşrulaştırıcı tavrında olduğu gibi hayal kırıklığı yaratmıştır. Ancak sansür gerekçesini rasyonel bir temele oturtma girişimi bu hayal kırıklığını kısmen gidermektedir (Platon, 2017: 348-349).

Hegel, sanata ilişkin yaklaşımında Plato'nun, taklit konusundaki düşüncelerine taklit bağlamında katılır gibi görünmektedir ancak sanatın taklitten öte bir değerinin de olduğunu düşünmektedir (Hegel, 1986: 140-143). İnsanın ve toplumun genel olarak tarihsel bir diyalektiğin, sentezin ürünü olduğunu düşünen Hegel, bu sentezde estetiğin ve sanatın rolüne önemli ölçüde vurgu yapar. Çünkü Hegel, sanatın, Tin'in kendini dışsallaştırmasının bir yolu olduğu kanısındadır. Hegele göre, sanat 'Tin'in gereksinim duyduğu bir şeydir ve 'Tin' sanat aracılığıyla duyusal bir görünüşe kavuşur, kendini, öz-bilincini açığa vurur (Hegel, 1986: 134-138). Toplumsal yapının tüm alanları sanattan bir şekilde yararlanır.

Kuşkusuz birçok düşünür sanata ilişkin, birbirinden farklı görüşler belirtmiştir. Raymond Williams, The Long Revolution (1965) kitabının 'Creative Idea' başlı̆̆ı altında Antik Yunan'da sanat kavramını tartışmakla birlikte Rönesans teorisinin heyecanından ve karmaşasından dört sanat doktrininin doğduğu bilgisini vermekte ve günümüze kadarki sanat yaklaşımlarını tartışmaktadır. Bunlardan ilki sanatı, gizli gerçeğin bir 'taklidi' olarak tanımlar ve böylece sanatı, bir açığa vurma/ ifşa etme formu olarak görür. Bu yaklaşım, ilerleyen zamanlarda sanatı Tanrı düşüncesinin alegorisi olarak nitelendirecek olan Hıristiyan düşünürler için kullanışlı olmuştur. Bu tutum, ezoterik bir etkinlik, sembolik ya da alegorik bir türün barındırdığı yapıtlara ilişkin yüksek değer şeklindeki sanat düşüncesi eşliğinde giderek gelişmiştir. Huristiyan düşünürlerden görece daha az etkilenen ikinci doktrin ise sanatı sonsuz bir taklit ve 'Güzellik Düşüncesi'nin somutlaştırılması olarak algılamıştır. Pratikte bu yaklaşım, körü körüne değil de ciddi bir biçimde, taklit etme fikrini, yani bu Güzellik Düşüncesi' nin somutlaştırıldığı daha erken dönem sanat yapıtlarını kapsama noktasına ulaşmıştır (klasisizm olarak bilinen bu yaklaşım önemli bir geleneğe dönüştü). Aristo'nun vurguları doğrultusunda gelişen üçüncü doktrin sanatı, doğanın idealleştirilmesi olarak değerlendirmiştir. Gösterilen şeyler oldukları gibi değil de olmaları gerektiği gibi betimlenmeli, ideal halleriyle sunulmalıydı. Bu doktrin, örnek alınacak önemli bir geleneğe, yani öğretici ve ahlaki yapıtlara doğru kaymıştır. 'Yaratıcı' vurgusunun temel olarak kaynaklandığı dördüncü doktrin ise doğayı Tanrının sanatı (Tasso), sanatı ise doğayla boy ölçüşen bir enerji formu olarak gördü (Williams, 1965: 22).

\footnotetext{
${ }^{1}$ Ayrıtılı bilgi için bkz. Dursun O., Yıldız F., Bulut S., "Dichotomy between War and Visualization of War / An Analysis of the War Photos Awarded by the WPP", Moment Dergi (Hacettepe Üniversitesi İletişim Fakültesi Kültürel Çalışmalar Dergisi), vol.6, pp.447-469, 2019.
} 
Aslında sanata ilişkin yaklaşımlar çeşitlilik gösterse de genel olarak iki eksen etrafında dönmektedir. Bunlardan ilki Platon'dan kaynağını alan ve sanatı taklit olarak gören indirgemeci yaklaşımken, diğeri sanatı üstün gerçekliği aktarma aracı olarak gören üstün sanat yaklaşımdır (Williams, 1965: 27). Williams'a göre, bir yüzyıllık süreçte tarzların önemli ölçüde çeşitlenmesine ve karmaşıklaşmasına şahitlik eden modern sofistik sanat düşüncesi, temsili, gerçekçi ya da natüralist olarak nitelendirilen bir sanat türü, en yaygın ve en objektif koşullar altında gerçekliğin yeniden üretimini ve sıradan bir tanımını sunmaktadır. Williams, romantik olarak adlandırılan diğer bir sanat türünün ise, gerçekliğin yalnızca bir temsilini değil, gerçekliğe yönelik sanatçının öznel duygusal tepkileriyle değiştirilen bu temsili de ortaya koyduğunu, yani gerçekliğin sanatçının kişisel vizyonuyla örgütlendiğini, seçildiğini, idealize ve karikatürize edildiğini belirtmektedir. Soyut olarak adlandırılan üçüncü tür ise, ne gerçekliğin yeniden üretimidir ne de gerçekliğin öznel bir değerlendirmesidir; arı 'estetik' deneyimin doğrudan ifadesi, gerçekliğin değil de sanatçı vizyonunun sanatta temsilidir (Williams, 1965: 35). Williams, kültüre bir yaşam tarzı olarak yaklaştığı gibi sanata da böyle yaklaşmıştır:
(...) Sanatın yaratılan bir olgu olduğunu düşündüğümüz gibi, kendi insani dünyamızı da yaratıyoruz. Sanat, tam anlamiyla bu yaratımın temel bir aracıdır. Bu nedenle sanatın sıradan yaşamdan ayrıştırılması ve kullanışsız ya da ikinci el gibi değersizleştirilmesi (bir 'boş zaman etkinliği' gibi), aynı hatanın alternatif formülleridir. Ë̆ger tüm gerçeklik, tanımlama çabasıyla başarılı biçimde öğreniliyorsa, saygı ve saygısızlık adına 'gerçekliği' yalıtamayız ve sanatı gerçekliğe zıt biçimde konumlandıramayız. Ĕ̆er tüm etkinlikler, paylaşılan tanımlarla öğrenilen yanıtlara bağlıysa, çizginin bir kenarına 'sanat'ı, diğer kenarına 'yapıt'ı koyamayız. Eşdeyişle, 'Estetik İnsan' ve 'Ekonomik İnsan' şeklindeki bölünmeyi kabul edemeyiz (Williams, 1965, s. 54).

Başka bir anlatımla kültür de sanat da sıradandır. Gündelik yaşamın deneyimlerinin ürünleridir. Bu açıdan Williams'in sanat yaklaşımı ne öykünme indirgemecidir ne de üstün gerçeklik olarak üstencidir; ona göre sanat sıradandır ve gündelik yaşam deneyimlerinin bir sonucudur.

\section{Failin Şiddetinin Maktul Üzerinden Gizlenmesinde Sanatın Rolü}

Yukarıda değindiğimiz gibi sanata yaklaşımlar çeşitlilik göstermektedir. Bu çalışma, sanatın zaman zaman bireyin duygusal yanına seslenerek rasyonel yanı olumsuz etkileyebildiği düşüncesinden hareket ettiği için, büyük ölçüde Platon'un sanat yaklaşımı ekseninde ilerletilmiştir. Ama bu eksen Platon'un sanatı taklit olarak ele aldığı eksen değil; duygusal/anti-rasyonel yana hitap ettiğini düşündüğü eksendir. Platon, sanatçının, bireyin duygusal yanına hitap ederek rasyonel parçayı yok ettiğini düşünmektedir. Aşağıdaki alıntıda dikkat çeken ve günümüzde, bilhassa sinema ve televizyon temel olmak üzere, kitle iletişim sistemlerinde de işleyen bir ilke mevcut gibidir. $\mathrm{O}$ da, şairin ya da daha genel ifadeyle sanatçının başarısının, neşelendirme gibi olumlu duygu üzerinden değil de coşturma, korkutma, hüzünlendirme ya da ağlatma gibi olumsuz duygular üzerinden temellendirilmesidir.

İon: Gösterdiğin kanıtlar o kadar ezici ki Sokrates. Açıkça söyleyeyim; içli bir parça okurken gözlerim yaşla dolar, korkar ve dehşet saçan kısımlarda yüreğim ağzıma gelir, saçlarım diken diken olur.

Sokrates: Kendi duyduğunuz şeyleri, çevrenizdeki seyircilerin çoğunluğuna da duyurduğunuzu bilir misiniz?

İon: Bilirim, bilirim. Ben anlattıkça onlar da benim gibi ağlar, yahut öfkeyle bakar veya titrerler. Ben sahnedeyken onların gösterdikleri tepkileri göz önünde tutmam yüzde yüz gerekir. Çünkü onları ağlatırsam kazancım yüksek olur, ben gülerim; yok gülmeye başlarlarsa bizim ücret hapı yutacağı için bana ağlamak düşer (...) (Platon, 2016: 269).

Platon, insanın iki yanının olduğunu düşünür: iyi yan ve akılsız, gevşek, korkak yan. Bu nokta Platon'un sansüre ilişkin düşüncelerinin rasyonel temele oturmaya başladığ 1 noktadır. İyi yan aslında rasyonel olan yandır, diğer yan ise kitlesel nitelikli irrasyonel ve hazcı yandır. Şairin ya da ressamın benzetme yoluyla hitap ettiği yan, bu kitlesel irrasyonel ya da duygusal yandir (Platon, 2017: 348-349):

Öyleyse ona çatmakta [şaire, yn], onu ressamla bir çuvala koymakta haklıyız. Gerçeğe yakınlık bakımından onun yaptığı da pek değerli bir şey değildir. O da içimizin iyi yayını bırakıp daha az değerli yanını ele alıyor. (...) içimizdeki kötü yanı uyandırıyor, besliyor, güçlendiriyor; böylelikle de aklı yıpratıyor. En akıllıları yok edip kötüleri başa getiren bir devlet ne hale gelirse o hale sokuyor insanı. Benzetmeci şair, her insanın 
içinde kötü bir düzenin kurulmasına yol açıyor, akla aykırı yanımızı gıdıklıyor (...) (2017: 349).

Aslında sanatçı Platon'a göre gerçekliği gizlemekte ya da görememektedir. Taklit ile gerçeklikten iki adım uzaklaşmaktadır. Böylece aklın rasyonel yanına hitap etmek şöyle dursun, irrasyonel yanının maddi hazlarını coşturarak, insanı gerçeklikten, asıl üzerine düşünmesi gereken şeyden kopartmaktadır. Platon'a göre, tutku gibi, öfke gibi içimize hoş veya acı gelen ve ister istemez gündelik hayatımıza giren duygular şiir yoluyla benzetmenin/ taklidin etkisi altındadır. Benzetme, yani taklit, insanı bu tür duygulardan kurtarmak yerine, bu duyguları besleyerek iyi ve mutlu olmamızı engeller ve mutsuzluğa ve kötülüğe sürüklenmemize neden olur. Başıboş sanatçıyı devletinden atan Platon, aklın gereğine uymayı bir ödev olarak kabul eder (Platon, 2017: 351):

Gözyaşı dökmek, dilediği gibi inlemek, acıdan bağırmak isteyen yanımız [irrasyonel] değil mi? İşte yaradılışımızdan bu isteklere çevrili yanımızı doyurmak ister şairler. (...) En iyi yanımıza gelince, akıl ve gelenek bizi tutmazsa, gözyaşları karșısında yumuşar, başkalarının felaketlerine ağlamayı ayıp saymayarak kendimizi acıma duygularına bırakır, alkışlamayı küçüklük saymaz, tersine iyi bir insanın buna ağlaması gerektiğine, bu şiirden aldığg zevkin faydalı bir zevk olduğuna, bütün şiirleri atmakla bu zevkten yoksun kalacağına inanır (Platon, 2017: 350).

Platon'un sanata dair düşünceleri, İsa'nın doğum yılı olarak kabul edilen tarihten yaklaşık 350 yıl önceye uzanır. İsa, 33-35 yaşlarında çarmıha gerilerek öldürülür. Yahudi Konseyi olan 'Sanhedrin', İsa'yı, düzeni bozmak suçundan yargılamış ve ardından Yahudi Valisi Pontius Pilatus'a sevk etmiştir. Pilatus, İsa'nın öldürülmesini emretmiş ve ardından İsa, çarmıha gerilmiştir. Luka'nın 23. ve 24. ayetlerinde hikâye şöyle devam eder: Yusuf, cesedi çarmıhtan indirip keten beze sarmıș ve kayaya oyulmus bir mezara yatırmıștır. Buna Celile'den gelen kadınlar da şahitlik etmiştir. Birkaç gün sonra kadınlar, hazırlamış oldukları baharatı alıp mezara gitmişlerdir, ama içeri girince İsa' nın cesedini bulamamışlardır. Kadınlar şaşırıp kalmışken, şimşek gibi parıldayan giysili iki kişi bir anda belirivermiştir. Korkudan başlarını yere eğen kadınlara, bir anda orada beliren iki adam, "Diri olanı neden ölüler arasında arıyorsunuz? (...) O burada yok, dirildi. Daha Celile'deyken size söylediğini anımsayın. İnsanoğlunun günahlı insanların eline verilmesi, çarmıha gerilmesi ve üçüncü gün dirilmesi gerektiğini bildirmişti." (Luka, m. 23-24).

İsa'yı, aslında siyasi bir. güç, yani dönemin mevcut inanç sistemi olan Yahudilik öldürmüştür. Dönemin Roma İmparatorluğu, kurumsal ve kültürel yapısını korumak, yani varlığını sürdürmek için alternatif bir gücün yükselişini ya da yeni bir doktrinin gelişimini engelleyebilmek amacıyla Tanrının oğlu İsa'yı öldürmekten imtina etmemiştir. Hikâyeye göre İsa nın hangi gerekçeyle, nasıl ve kim tarafından öldürüldüğ ü oldukça açıktır. Ama dönemin sorgulama ya da adalet sistemi -gerçek anlamda olmasa da simgesel anlamda- yeterince tartışılmamıştır. En azından günümüzdeki mevcut alg1, yani görsel-simgesel anlatı, İsa'y1 öldürenler üzerinden değil, İsa'nın ölüm şekli ve sonrası üzerinden inşa edilmiştir. Hatta İsa'nın müritlerini telkin etmek için, O'nun Tanrı katına yükseldiğgi düşüncesiyle yetinilmemiş, ilaveten kıyamete yakın bir gün geri döneceği ve normal bir insan gibi öleceği de hikâyeye eklenmiştir (Luka, m.23-24).

Bu anlatı, İsa'nın müritlerini, insanın uyguladığı adaletsizlik karşısında uysallaştırarak üzüntülerini azaltmayı ve İsa'yı insana aşkın bir bağlama konumlandırarak mevcut adaletsizliğin üzerini örtmeyi amaçlayan bir anlatıdır. Aksi durumda suçlu ortaya çıkacaktır ki bu da yönetici güçtür. Berger' in (2014: 86-87), sanatın her dönemde yönetici sınıfların emrinde olduğu, bilhassa da 1500-1900'lü yıllar arasında Avrupa sanatının, değişik formlarda kapitalin yeni gücüne dayanan yönetici sınıflara hizmet ettiğini belirtmektedir. Hatta "saray sanatçısı" ifadesi dahi doğmuştur:

Sanat tarihçilerinin saray sanatçısı dedikleri kișiler, hükümran prensler tarafından görevlendirilerek öteki zanaatçı/sanatçı meslektaşlarının çoğunluğundan ayrılan ve bu seklide de yüksek statülerini hak ettiklerini gösteren ressam, heykelci ve mimarlardi. (...) Genellikle tipik "Rönesans Sanatçısı" olarak anılanlar işte bu bir avuç "saray tedarikçisi" dir. Gerçekte saray sanatçlıranın çoğu, yeme içme ve konaklama masraflarının dışında, yıllık maaş alıyordu ve işverenler de bunlara karşıllı kendilerinden portre çizmelerini ve saray odalarının dekorasyonunu yapmalarını ya da, kimi durumlarda, mobilyaları ve mücevher mahfazalarını boyamalarını (Cocimo Tura), goblen ve kase tasarlamalarını (Mantenga) ya da şenlik ve kostüm hazırlamalarını (Leonardo) isterlerdi. Saray sanatçllarının çoğu ... eserlerini... sipariş üzerine ve özgül bir işlevi gözeterek yapiyorlard1 (Shiner, 2018: 78-79).

Leppert'in, Batılı imgelerin genellikle seyircilerin kurbanlara sempati duymasinı 
sağlamayı amaçladığını, sanatın öncelikle resmi kurumların çıkarlarına hizmet ettiğini, kurumsal ve kişisel iktidarı yayma ve sürdürme görevi üstlendiğini ifade etmesi, İsa' ya ilişkin anlatıları daha da anlaşılır kılmaktadır. Resmin bir kurbanlar repertuarı, en kutsal kurbanın ise çarmıha gerilen İsa olduğunu ve suçsuz yere cezalandırılan diğer bedenlerin tümünün, Issa'nın bir türevi şeklinde resmedildiğini belirten Leppert şöyle devam etmektedir (2017: 167):

Kilise için resim, okuma yazma bilmeyen bir halkın eğitilmesinin başlıca araçlarından biriydi. Bu amaçla kullanılan resim, azizlerin hayatları ile-kilisenin, Engizisyon işkenceleri gibi o günün cezalandırma eylemlerinin bizzat içinde olmasına rağmen- genellikle seküler otoriteye direndikleri için cezalandırılan şehitler üzerinde yoğunlaşıyordu. Dolayısıyla, seküler otoritenin masumlar üzerindeki işkencelerini işleyen kapsamlı bir görsel arşiv oluşturdu kilise.

Kant, Güzellik ve Yücelik Duyguları Üzerine Gözlemler kitabında, yücelik ve güzellik duygularını birbirinden ayırarak irdeler. Kant (2010: 50-53), yücelik duygusunun ağır başlı, vakur ve ihtişamdan azade olduğunu söylemektedir. Kant'a göre, karla kaplı doruğu bulutların üzerinde yükselen bir dağın görüntüsünü, Milton'ın cehennem krallığı betimlemesini, şiddetli bir fırtınanın tasvirini yeterli güçte edinebilmemiz için yücelik duygusuna; çiçekli, derelerin kıvrılarak aktığı ve sürülerin yayıldığı vadi görüntüsü, Elysium tarifi, Homeros'un Venüs kemerine ilişkin betimlemesinin hoşluğunu ve şenliğini yaşamamız için ise bir güzellik duygusuna sahip olmamı gerekir. Kant, gecenin yüce, gündüzün güzel olduğunu ifade eder. Yüce, harekete geçirici iken, güzel, büyüleyicidir. Yücelik duygusuna bazen belirli bir korku veya melankoli, bazen asude bir merak, bazen de yüce bir planı tümüyle denetimine almış bir güzellik eşlik edebilir. Derin yalnızlık, korku uyandırsa bile yücedir. Yüce her daim büyük olmalıdır. Güzel bezenebilir, süslenebilir fakat yüce yalın olmak zorundadır. Büyük bir yükseklik, büyük bir derinlik, uzun bir süre de yine Kant'a göre yücedir. Kant için, yüce ihtişama, süslenmeye fazla gereksinim duymaz. Yüce için önemli olan, soyut duyguları derinden harekete geçirmektir.

Bolla (2012: 49-51), Amerikalı sanatçıların, yücelik duygusunu yaratamamalarının nedenini, Amerika'nın Avrupa gibi bir tarihe sahip olmamasına bağlarken, yücelikle ilgili şu ifadeyi kullanır: "Bu yüce içerik, geçmişte anlatımsal, tarihsel ya da ibadetle ilgili olsun, sanatın önemli konu malzemesini oluşturmuştur." İnancın görselleştirilmesi -özellikle Avrupa sanatında-, yücelik duygusunu, büyük ölçüde güzellik üzerinden derinden hissettirme felsefesi üzerine kuruludur. Zizek (2011a: 95-96), Hiristiyanlığın İsa'y1 yüceltmek ya da yüce tözünü görünür kılmak için, O'nu gösterişli bir şekilde görselleştirmek yerine, tam tersini yaparak, bir paradoks yaratarak en alt düzeye indirme yoluyla görselleştirdiğini ifade eder. “(...) gösterimsel düzeyde İsa "bir adamın oğlu", iki sıradan haydutun arasında çarmıha gerilen, üstü başı dökülen, sefil bir yaratıktı: bu dünyevi görünümün tamamen sefil manzarasının oluşturduğu geri planda ise onun kutsal özü çok daha kudretli bir biçimde parlar."

Yukarıda değinilen simgeselleştirme-görselleştirme, inanç sistemlerinin genelinde mevcuttur. İnanç tarihine yön veren insanlar ve kurumlar, döneminin iktisadi ve siyasi olarak güçlü insanları ve yapıları olmasına rağmen, her zaman gösterişten uzak ve hatta yoksul bir biçimde sanata ve sanatçıya konu olmuştur. Çünkü Tanrı, teoride yoksulun yanındadır, yoksulu korumakla mükelleftir. Ama uygulamaḑa yoksul, hep zulüm görmüştür. Yoksulluğunun bedelini bu dünyada öderken maruz kaldı ̆̆1 acıları, öbür dünyada kendine yer edinme düşüncesiyle bastırabilmiştir. Aslında burada işleyen mantık, kutsalı zenginihtişamlı biçimde görselleştirerek özdeşleştirme yoluyla az sayıda elit ya da yönetici bir grubu etkileme değil, yoksul biçimde görselleştirerek kitleleri denetim altında tutmanın mantığıdır. Toplumları, sayıca az olan yöneticiler ya da elitler oluşturmaz, sayıca çok olan kitleler oluşturur. Ónemli olan, sayıca az yönetici ya da elit kesimin, kitleleri denetim altına alabilmek için onların çeşitli duygularına hitap ederek hem yatıştırmak hem de mevcut sistemde uysal bir şekilde tutabilmektir.

Berger, 16. ve 17. yüzyılların yağlıboya resimlerinin, zenginlerin dürüst ve çalışkan, hiçbir işe yaramayanların ise hiçbir şeye sahip olamaycağ kılmaya çalıştığını belirtmektedir. Berger'e göre, bu resimler, gündelik yaşamı tarif ederken de benzeri bir tutum takınıyordu. Yağlı boya tablolarında fakirler, varlıklı insanlara gülümsüyor ve böylece hem kendilerini kabul ettirmeye hem de bu yolla zenginlere birşeyler satmaya, onlardan birşeyler koparmaya çalışıyorlardı; yoksullar mutlu, varlıklılar ise dünya için bir umut kaynağı olarak tasvir ediliyordu (Berger, 2014: 103-104). Başka bir anlatımla, kitleler talepkar, yöneticiler ise hep gönlü bol insanlar olarak anlatılıyordu. Bu anlatı, hem kitleler hem de yöneticiler tarafından kanıksanmıştı.

Le Bon'a göre, kitleler "majik (büyüsel)" gücün egemenliğinin denetimindedirler. Bu 
büyüsel güç hem kitleler üzerinde güçlü fırtınalara neden olabilmekte hem de onların en şiddetli fırtınalarını dindirebilmektedirler (akt. Freud, 2015: 19). Le Bon, kitlelerin irrasyonel olduğu düşüncesindedir. Aşırılıklara eğilimli olduğundan, onları coşturup heyecanlandırmak da yine aşırı uyaranlar sayesinde gerçekleşir. Kitleleri etkilemek için kullanılacak argümanların akıl süzgecinden geçirilmesine gerek yoktur. İşi, aşırı güçlü imgelere dökmek, abartı kullanmak ve aynı şeyi sürekli tekrarlamak, kitleleri etkilemek için yeterlidir. Çünkü kitle "gerçek" ve "düzmece" konusunda kuşkuya düşmez; kendinden güçlü bir varlığ ın bilinci dâhilinde yaşar; otoriteye bağlı ve aynı zamanda hoşgörüsüzdür. Güce saygı duymasından dolayı, iyilikçi davranışlardan pek fazla etkilenmez. Le Bon, kitlelerin, üstün gördüğü kişilerden beklediğ i davranışın, güçlülük ve hatta zorbalık olduğunu ifade eder. Kitleler, egemenlik ve baskı altına girme ve efendisinden korkma eğilimi sergiler. Geleneksele oldukça saygı gösterir ve bu nedenle de tutucu, yeniliklere ve ilerlemelere de kapalıdır $(2015$, p. 18). Kuşkusuz, kitleleri bu şekilde ötekileştirmek ve aşağılamak doğru değildir ama kitle psikolojisini anlamlandırabilmek için Le Bon' un ifadelerini dikkate almak önemlidir. Bourdieu (1991: 163-164), sembolik şiddetin kendisini karşılıklı talep ilişkisi içinde gösterdiğini söyler. Sembolik şiddeti uygulayan bir gücün karşısında, bir de bu şiddete maruz kalmak isteyen bir tarafın mevcudiyetinden söz eder. Sembolik gücün, istenilmediği sürece kimseye uygulanamayacağını belirten Bourdieu, sembolik şiddete maruz kalanı da suç ortağı olarak ilan eder.

Zizek, siyasete Lacancı bir fantezi olarak yaklaşmaya çalıştı̆̆ı yazısında, medyanın bir fantezi yaratarak olayları politikliğinden ya da gerçekliğinden uzaklaştırdığını anlatır. Kalküta, kültürel faaliyetlerle dolup taşan, kültürel olarak Bombay'dan daha gelişkin olan, tam bir sosyal hizmetler ağına sahip başarılı bir Komünist belediyeye sahiptir. Fakat Rahibe Teresa' nın misyonerlik faaliyetleri için şehir, fantazmatik ekranda Yeryüzü Cehennemi olarak sunulur. Toplumsal çürümenin, yoksulluğun ve şiddetin merkezi olduğu ve sakinlerinin ölümcül bir apatiye yakalandığ1 yozlaşmış Ưçüncü Dünya megalapolisinin bir örneği olarak yansitılır. $\mathrm{Bu}$, misyonerlik işleri yapmaya çalışan Rahibe Teresa'nın işini kolaylaştırır. Böylesine bir karamsar tabloda Rahibe Teresa, mazlumlara ümit ışı̆̆ olur, yoksulluğun bir selamet olarak kabul edilmesi şeklinde mesajlar yayar. Zizek (2011b: 150-151) şöyle devam eder:

\begin{abstract}
... çünkü yoksullar üzücü kaderlerine sesiz bir vakar ve imanla tahammül ederek İsa'nın yolunu izlemektedirler. Bu işlemin çifte ideolojik yanı vardır: yoksullara ve ölümcül hastalara selameti tam da çektikleri istırapta aramalarını önerdiği sürece, Rahibe Teresa onları içinde bulundukları müșkül vaziyetin nedenlerini kucaklamaktan - yani durumlarını politize etmekten- alıkoyar. Aynı zamanda Batılı zenginler de, Rahibe Teresa' nın yardımseverliğine mali katkılarda bulunarak bir tür ikame-selamet imkânı sunar. (...) Yeryüzü Cehennemi olarak, orada çekilen acıyı herhangi bir siyasi faaliyetin değil ancak ve ancak iyilikseverliğin ve şefkatin giderebileceği ölçüde viran bir yer olarak Üçüncü Dünya imajının yerleştirilmesi sayesinde yapılır.
\end{abstract}

Shiner (2018: 94), bugün müzelerde sergilenenlerin neredeyse tümünün, sipariș üzerine ve belirli mekanlara yönelik tasarlanmış materyaller olduğunu söyler ve şöyle devam eder: "Müzeyi gezerken, 'etrafları paravanlar, gölgelikler, uçan melekler ve asılmış devekuşu yumurtaları, mumlar ve kandillerle çevirilmiş olan' dinsel eserlerin esas bağlamını tahayyül etmek çok zor." Kuşkusuz, Avrupa, Rönesans aracılığıyla sanat üzerinden, din gibi kültürel kurumları yüceltme girişiminde bulunmuştur. Hiristiyanlık, giderek sanatsallaşmıştır. Hıristiyanlığın sanatsallaşması, Rönesan ile üst noktalara ulaşmıştır. Aydınlanmanın temelini oluşturan Rönesans, diğer taraftan geleneği de canlı tutmaya çalışmış, rasyonel aklı en ąıından sanatsal düzeyde kısmen devre dişı bırakmıştır. Hegel (1986: 167), Rönesans dönemi İtalya'sında resim sanatının, dinsel saygının ve içe dalışın yalın görkemliliğine odaklandığını dile getirmektedir. Hegel'e (1994: 101) göre, din, insanda dini hakikatı sembolize ederek canlandırmak amacıyla sanatı kullanmıştır.

Hıristiyanlığın ahlaki gelişimi ve bu ahlakın simgeselleştirilmesi ilk dönemlerde hep İsa'nın ölümünü -klasik bir sahne olan çarmıh dışında da - görselleştirerek, acısını kitlelere hissettirmek şeklinde olmuştur. Katedrallerin, kiliselerin ve kutsal mekânların ve hatta Batı saraylarının duvarları, Tanrı'nın oğlu İsa'nın ölümünü anlatan tuvallere dönüştürülmüş; bahçeler ve kamusal alanlar yine İsa' nın ölümünü anlatan heykellerle donatılmıştır.

Bu dönemde anlatı, genel olarak öldüren fail üzerinden değil de ölen maktul üzerinden simgeselleştirilmiş ve maktul genelde yüceltilmiştir. Suçluyu tespit etmek kolay olsa da onu yargilamak ya da cezalandırmak o kadar kolay değildir. Bu nedenle, tarih genel olarak failin uyguladığı şiddeti, maktul üzerinden anlatmış, simgeselleştirmiştir. Nietzsche, Ahlakın Soykütü̈öü Üstüne (2017: 66-67) eserinde, tarihin Yahudi'ye karșı Roma ya da Roma'ya karş1 Yahudi ikiliğinde kurulduğunu ifade etmektedir. Halkçı ve rahip Yahudi ile aristokrat Roma çekişmesinde, günümüzde insanlığın yarısının Roma'daki sözde en yüksek değerlere sahip 
insanların önünde eğilerek evcilleştiğini ifade etmektedir. Nietzsche' ye göre, Hıristiyanlık âlemi, ụç Yahudi erkek (Nasıralı İsa, Balıkçı Petrus, Halı Dokuyucusu Paulus) ve bir Yahudi kadın (İsa'nın annesi Meryem) öncülüğünde evcilleştirilmiştir.

Burada Platon'a dönecek olursak, tarihin fail-maktul ilişkisinde, rasyonel davranarak faili bularak sorgulayabilecek olan akıllı yanı baskıladığını, irrasyonel olan duygusal yanı coşturduğunu, böylece de insanın itaatkârlığını, irrasyonalitesini kutsadığını söylemek yanlış olmayacaktır. Fakat yaşam ne tümüyle rasyonel ne de tümüyle irrasyonel bir zeminde yaşanabilir. Akla ve yargılama gücüne sahip olan insan aynı zamanda duygulara ve hazlara da sahiptir. Platon'un tümüyle reddettiği insanın akılsız-kötü yanı da yeri geldiğinde tatmin edilmek zorundadır. Aristoteles (bkz. 2018), aklı logos ve alogos olarak ikiye ayırdığında, bu iki yanı tümüyle birbirinden koparmaz. Erdeme ya da kendinde amaç olan mutluluğa ne sadece logosla ne de sadece alogosla ulaşılabilir. Bu meziyetlere ulaşmak, iki aklın birbiriyle diyalektiğinin bir sonucudur. Aristoteles'e göre iyi yaşam ölçülü yaşamdır, orta olma durumudur. Bu da bir bütünlük arz eder. Bu nedenle, Platon'u tümüyle kabul ederek, gündelik yaşamin pratiklerinde eylememiz mümkün değildir. Burada bir orta olma şeklinde bir konum benimsemek önemlidir.

Hıristiyanlık tarihi, toplumsal süreçleri görselleştirme yoluyla simgeselleştirirken bir mantıktan, tarihsel süreçte şekillenmiş Hıristiyan Batı bilincinden hareket etmiştir. Bu bilinç, günümüzde de hala varlığını korumaktadır. Kuşkusuz aklımızın bazen rasyonel bazen de irrasyonel yanına hitap edilmesini talep ederiz. Bu tür bir talep, sorun değildir. Fakat rasyonellik-irrasyonellik talebini ne üzerinden yaptığımız önemlidir. Bir sanat eserinin daha çok irrasyonel yanımıza hitap etmesini istememiz anlaşılır olabilir. Ancak haber medyasından böyle bir talepte bulunulması doğru değildir. Haber medyası, olabildiğince rasyonel yanımıza hitap etmelidir. Bu, haberde tarafsızlık/nesnellik adına önemlidir. Ayrıca, hem görüntünün barındırdı ğı insanların kişilik hakları açısından hem de izlerkitle üzerinde yaratacağı etkiler açısından bu tür görselleştirmelerden uzak durulmalıdır. Bu, birçok akademik çalışma tarafından dile getirilmiştir. Fakat Türkiye'de gazetecilik mesleğini icra edenlere yönelik Türkiye Gazeteciler Cemiyeti tarafından hazırlanan Türkiye Gazetecileri Hak ve Sorumluluk Bildirgesi de haber medyasında bu türden içeriklere ve anlatılara etik açıdan değinilmemesi kanaatindedir:

Cesetleri yakın plan gösteren, kan ve şiddet unsurları içeren fotoğraflara yer verilmemelidir. Gizli kamera gibi teknolojik yöntemler sadece yayınlanmasında kamu yararı olan ve başka türlü elde edilemeyecek istisnai durumlarda kullanılmalıdır.... Ölümlere ilişkin haberlerde sansasyonel ve acıları artıracak üslup kullanılamaz. Insanlarda travma yaratacak kan ve şiddet içeren fotoğraflara yer vermez, saldırının sonuçlarını korku ve yılgınlık yaratacak biçimde büyütmez." (TGC, 2019).

Habercilerin davranış kuralları ya da haber anlatıları ve görsel kullanımları etik bağlamda sürekli tartışılmaktadır. Yukarıdaki metinde yer alan ifadeler, habercilerin ve haber anlatılarının etik bağlamda sınırlarını net bir şekilde çizse de uygulamada aksi durumlarla karlışalışmaktadır.

\section{Haber Medyasının Mağdurun Duygusallığını Kullanması}

Haber medyası, ölüm ve şiddet olaylarını anlatırken anlatıyı genel olarak mağduru yüceltecek ve faili ise gizleyecek şekilde kurgulamaktadır. Özellikle günümüzün temel sorunlarından olan istismar, kadına yönelik şiddet ve kadın cinayetlerinin sunumunda bu tür anlatılar ve görsel kullanımları dikkat çekmektedir (Köker, 2007, 139-140; Alankuş, 2007; Dursun, 2010; Wilkins, 1995). Bu, gazetelerin başarısının tirajla, televizyonların reytingle ve internetin ise tıklanma sayısı gibi rasyonel ve doğru olmayan yöntemlerle belirleniyor olmasından kaynaklanmaktadır.

McGregor, görselleştirmeyle ilişkili ikinci yeni bir haber değerinden söz etmektedir. Aquinas'ın duyulan şeylerden daha ziyade görülen şeylerin duyguları daha etkili biçimde harekete geçirmek için kullanılabileceği şeklindeki düşüncesini aktaran McGregor (2002), bir olayın duygusal alt metninin yoğunluğu, onun haber olarak seçilme olasığılını yükselttiğini ifade eter. Bir olay, trajedi, insani ikilemler, mağdurlar, çocuklar ve hayvanlar gibi ortak haber unsurlarını içerdiğinde duygu yükü ve buna bağlı olarak da haber olma ihtimali artır. Aynı şekilde duygusal çekiciliğe sahip olaylar, izlerkitledeki duygusal tepkileri de uyandırmaktadır. "Eğer kan yoksa, haber değildir" şeklindeki eski kinizm, "Áğlamazsa, haber değildir" ile aynı anlama gelebilmektedir (McGregor, 2002).

Kadının toplumsal rollerini annelik alanı üzerinden kuran ataerkil bakış açısı çocuğun 
beslenmesi, sağlıklı biçimde yetiştirilmesi, hasta olduğunda bakımının sağlanması gibi görevleri annelere yüklemektedir (Butler, 2011; Sancar, 2014). Bu çerçevede şekillenen habercilik pratikleri de şiddet, ölüm, açılık ve yoksulluk gibi mağduriyetleri aslında sorunun hiç de nedeni olmayan kadın ve çocuk imgelerini, kadının çocuğuna karşı hassasiyeti, kaybetme korkusu, çocuğu aç kaldığında hissettiği çaresizliği alımlayıcılar üzerinde özdeşleşme ve dramatik etki yaratmak amacıyla kullanmaktadır (Östgaard, 1965; Kepplinger, 1989, Yıldız ve Ördem, 2018).

Haberde duygusallığın/mağduriyetin iyi sattığı aslında pratikte medya alanında uygulanmakta, teoride ise medya çalışmaları alanında sıklıkla dile getirilmekte ve eleştirilmektedir (TGC, 2016, s.38-45; Baran vd, 2017). Bu tür örneklere sadece haber medyasında değil, medyanın birçok alınında rastlanmaktadır. Örneğin televizyon ve sinema sektöründe de benzeri davranışlarla karşılaşmak mümkündür. Acı ve gözyaşının yüksek olduğu, kadının dramatize edildiği dizilerin reytingi, sinemaların ise gişesi yüksek olmakta ve yapım şirketleri, yapımlarında bu etkiyi dikkate alabilmektedirler (Çakar Bikiç ve Ağaoğlu Ercan, 2019).

$\mathrm{Bu}$ çalışmanın temel konusu olan fotoğraf hem teknik hem de içerik olarak gündelik yaşamımıza bir anda girmiş değildir. Teknik olarak bir yüzyıl gibi süreçte mevcut olabilmişken, içerik olarak kendinden önce mevcut olan oldukça uzun bir tarihsel sürecin göresel sanatlarından yararlanmıştır. Fotoğraf bununla kalmamış, kendinden önceki görsel sanat tekniklerinden, içeriklerinden beslenerek kültürel/sembolik anlatı ya da ideoloji anlatı aracına dönmüş ve kitleleri etkileyebilecek gücünü kazanmıştır. Kendinden sonra gelen görselişitsel sanatların görsel anlatı tekniğine de kaynaklık etmiştir. Başka bir anlatımla sinema ve televizyon gibi hareketli görüntünün elde edilmesinin temelini oluşturan fotoğraf, bu alanlara sadece teknik açıdan esin kaynağı olmamıştır, aynı zamanda kendinden önce varolan görsel sanatlardan esinlenerek edindiği sembolik anlatı gücüne kendi gücünü de ekleyerek, bunu sinema ve televizyona da aktarmıştır (bkz. Kracauer, 2015, s. 105-115).

Aslında sanatlar araçsal olarak birbirinden ayrı dursalar da amaçsal olarak birbirlerine benzemektedirler. Bu çalışmanın temel olarak üzerinde durduğu 'fotoğrafın sembolik anlatı yoluyla gerçeği görünmez kıldığı, duygusal akla hitap ederek maktulü yüceltirken faili gizlediği düşünceleri' sinema ve televizyon için de geçerli bir durumdur. Fotoğraf, dilinin evrensel oluşu ve sözlü/yazılı öğrelere göre izleyende daha güçlü hızlı etki bırakıyor olması nedeniyle, haber ve propaganda aracı olarak da kullanılmaktadır (Demirel, 2015, s. 762). Benzeri şekilde sinemanın da manipülasyon ve propaganda aracı olarak kullanıldığ 1 ve gelenekselkültürel yapıları yeniden ürettiği bilinmektedir (Rotha, 1995, s.39-47). Örneğin Tunalı (2006; 29), melodramın Hıristiyan-Batı için benzeri amaçlar yüklendiğini belirtir Tunalı, "Özetle 'melodram' ... ideolojik anlamda Hıristiyanlık öğretisinin dinsel motiflerini birer şablon niteliğinde günümüze kadar taşımıştır." ifadesini kullanarak, melodramın, gücünü büyük ölçüde Avrupa'nın din ve din dışı unsurlardan aldığını belirtir. Günümüzde sinemanın da baskın bir türü olan melodram Tunalı'ya göre (bkz. 2006, s. 18-21, 47-50), toplumsal-geleneksel kalıpları yeniden üretmekte ve özellikle kadınları bu kurallara bağımlı kılacak içeriklere yoğunlaşmaktadır. Bu çalışmada incelenen fotoğraflar için ileri sürülen, maktül olarak kadının ya da çocuğun yüceltilmesi, sinema gibi görsel-işitsel sanatlar için de geçerlidir, bilhassa da melodram bu açıdan oldukça işlevsel bir tür olarak karşımıza çıkmaktadır.

Kitle iletişim araçlarından olan ve özellikle eğlence yönü, tecimsel kaygılarla, ağır basan sinema, toplumsal yapı üretiminde, yapının yeniden üretiminde ya da yapının sökümünde, özetle simgesel üretim ve tüketim açısından, önemli ve güçlü bir etkiye sahiptir (Erbalaban Gürbüz, 2016, s. 134; 2018, s.346). 24 fotoğraf karesinin hareketi üzerine kurulan sinema ya da televizyon, fotoğrafın yaptığından daha fazla biçimde sisteme ve egemen ideolojilere hizmet edebilmektedir. Örneğin Amerikan ideolojisi sadece ekonomik-politik ve askeri alanda değil, Hollywood/Amerikan sineması gibi kültürel üretim alanında da belirgindir (Shin ve Namkung, 2008). Altman (2018, s. 153-154), film türlerine yaklaşımları ele aldığı çalışmasında, ritüel yaklaşımın, Hollywood'un, toplumsal baskılara karş1lık vererek izleyicinin arzularını dile getirdiğini, ideolojik yaklaşımın ise, Hollywood'un izleyiciyi kendi alanına dahil edebilmek için izleyicinin enerjisinden ve psikolojisinden faydalandığını belirtmektedir. Burada önemli olan, izlerkitleyi yakalayabilmektir, bu nedenle de ona hitap edebilmektir.

Kuramsal olarak kısaca değinmeye çalıştı̆̆ımız nokta, fotoğrafın, kendinden önceki sanatlardan her açıdan yararlandığı gibi, başta sinema olmak üzere kendisinden sonraki sanatlara da her açıdan temel teşkil ettiğidir. Resim sanatı, fotoğraf ve sinemanın ortak noktası görüntüdür ve görüntünün ideolojileri ve gücü sunma biçimleri ve becerileridir (Uzun Aydın, 2017, s.393). Görsel-işitsel sanatlar teknik olarak birbirlerinden farklllaşsalar bile, egemen ideolojinin beklentilerinden ve baskılarından kurtulabildiklerini söylemek olanaklı 
değildir. Hatta hegemonyaya hizmet ettiğini söylemek yanlış olmayacaktır. Bugün medya, birçok açıdan egemenin kıskacına girmiş durumdadır. Mağduru betimlemek ve olayı onun mücadelesi olarak göstermek ya da içeriği mağdurun durumuna kani gelmesine yönelik kurgulamak başarının kaynağına dönüşmüsş gibidir. Bu anlayış haber medyasından tutun da sinemaya kadar tüm kültürel üretim alanlarına sıçramış görünmektedir. Bu çalışmada analiz edilen fotoğraflar da aynı minvalde içeriklere sahiptir. Odül mekanizmasıyla başarılı kılınan fotoğrafların büyük bir bölümü acı, kan, ölüm, șiddet vb. temalar barındırmaktadır.

\section{Analiz Yansimast \\ İki Bin Yıllık Simgeselleştirme-Görselleştirme Bilincinin Basın Fotoğrafçılı̆̆ına}

Medya alanında üretilen içeriklerin birçoğu çeşitli şekillerde ödüllendirilmektedir. Filmler, diziler, belgeseller, müzikler, haberler, basın fotoğrafları, televizyon formatları gibi birçok içerik ve format -ki bunlar kültürel emtiadır-çeşitli kuruluşlarca ödüllendirilerek medya kuruluşlarına ve medya profesyonellerine çeşitli formlarda (iktisadi, sosyal, kültürel, sembolik) sermaye yüklenebilmektedir. Oscar, Cannes, Golden Globes, British Academy of Film and Television Arts, Emmy, Uluslararası Adana Film Festivali gibi sinema ve televizyonculuk; Emmy, MTV Video Music Award, Eurovision Song Contest gibi müzik; The Pulitzer Prizes, Magnum Photography Awards, Sony World Photography Awards, İstanbul Fotoğraf Ödülleri, World Press Photo Awards gibi fotoğrafçılık alanında ödül veren mekanizmalar, bu alanlarda üretilen kültürel ürünleri ödüllendirerek üreticilerine çeșitli formlarda sermaye kazandırmaktadır. Bu türden bir sermaye kazanabilmek içinse, mevcutlar içerisinde ayrıcalıklı bir emtia üretmek gerekmektedir.

Hollanda merkezli kurulus olan World Press Photo (WPP), 1955 yılından bu yana basın fotoğraflarını ödüllendirmektedir. Uluslararası nitelikli olan bu basın fotoğrafçılığı yarışması, fotoğrafçıları, ürünleri olan fotoğraflar üzerinden ödüllendirerek onları sembolik, sosyal, kültürel ve iktisadi sermaye gibi alanlarda güçlendirmektedir. Bourdieu'ya (1998: 56) göre, gazeteciler, kültürel üretimi ele geçiren gazetecilik alanının kontrolüne girmişlerdir. Bourdieu (1998; 2010) sosyolojisinde medya, kültürel üretim alanına denk düşer. Bu nedenle gazetecilik alanının birer parçası olan foto-muhabirleri, mesleklerini icra ederken kültürel bir üretim gerçekleştirirler. Bourdieu (ayrica bkz. 2006), The Forms of Capital (1986: 246) çalışmasında kültürel sermayeyi kendi içinde çeşitli formlara ayırır. Ödüllü fotoğraflar, bedenin yeteneğine göndermede bulunması açısından somutlaşmıș; fotoğrafçının bir kurum tarafından yetkilendirilmesinden dolayı kurumsallaşmış sermaye türleriyle bağlantı kursa da temel olarak kültürel birer meta oldukları için nesneleşmiş kültürel sermaye başlığı altına konumlanırlar. Bu kültürel sermaye, beraberinde üreticisine iktisadi, sosyal ve sembolik sermaye kazandırır. Çünkü tüm sermaye türleri birbirine çevrilebilirlik özelliği taşırlar (Bourdieu, 1986: 252-254). Ỏzetlemek gerekirse çekilen fotoğrafların medya kuruluşlarınca yayınlanması ve sonraki süreçte de ödüllendirilmesi foto-muhabirlerinin kültürel üretimde başarılı olduğu anlamına gelir. Böylelikle foto-muhabirlerine maddi ödül yoluyla iktisadi sermaye, ilişkiler ağının genişlemesi yoluyla sosyal sermaye ve alanda saygınlık kazanması yoluyla sembolik sermaye yüklenir. Fakat, bu başarı-ödül mekanizması farklı tartışmalara açıktır.

1981 yılında WPP'den Yılın Fotoğrafı ödülünü kazandığını duyan Mike Wells, “Beni utandırıcı bir duruma soktu. (...) Açlıktan ölmek üzere olan insanların resimleriyle ödüller kazanmak pek akıllıca görünmüyor." ifadesini kullanmıştır (WPP Koleksiyonu).

Rus Büyükelçisi Andrei Karlov'in 19 Aralık 2016'da Ankara'da bir serginin açılışında uğradığı silahlı saldırı sonucunda ölümünü kareleyen Associated Press Ajansı foto muhabiri Burhan Özbilici, bu fotoğrafıyla 2017 WPP ödülüne layık görülmüştür. Amerika'nın Sesi Radyosu'nun Özbilici ile yaptığı söyleşide, “Özetle bu O' nun yılı ve O da sonuna kadar bunun tadını çıkarıyor." ifadesi yer almaktadır. Söyleşide aşağıdaki ifadeler de konumuz açısından önem taşımaktadır:

... Ve ardından Özbilici'nin 13 Mart'ta gazeteciliğin Oscar'1 diye bilinen World Press Photo ödülünü kazandığı açıklandı. (...) Bu ödül Özbilici ismini dünyaya tanıttı. 'Terörist fotoğrafı ödüllendirilmemeli' diyen sesler de çıktı. Ama Özbilici, fotoğrafın 'gerçekçi ve aynı zamanda sanatsal gücü ağır bastığı için' büyük ödüle layık görüldü. (...) Birikimi, sabrı, soğukkanlılığı, aksansız Fransızca ve İngilizcesi’yle her gittiği ülkede gazete ve televizyonlara onlarca röportaj veriyor. Fotoğraf, internet 
ortamında 18 milyon kez indirilmiş. Bu süre içinde aralarında Amerika'daki Atlanta Photojournalism Seminar'ın "Y1lın Fotoğrafı" ödülü de dahil olmak üzere, birçok ödül de kazanmış (Çakır, VoA, 27.11.2017).

Rusya Federasyon Konseyi Enformasyon Politikası Komisyonu Başkanı Aleksey Puşkov, fotoğrafın ödüllendirilmesinden sonra "Şöyle bir izlenimim var: Andrey Karlov'un öldürülmesi fotoğrafının World Press Photo'nun en başlıca fotoğraf ödülü seçilmesi bir ahlaki kusur olmakta. Bu ödülün mazareti olamaz." (Safarov, Sputnik, 13.02.2017) açılamasında bulunmuştur. Fotoğrafı ödüllendiren jüri de aslında ikiye bölünmüştür. Jüri üyesi Stuart Franklin' in Guardian için kaleme aldığı "Bu terör imgesi, yılın fotoğrafı olmamalı. Karşı oy verdim" başlıklı yazısında (Franklin, Guardian, 25.11.2020) "Üzgünüm Burhan. Bu, bir cinayetin fotoğrafı, katil ve maktül aynı karede görünüyor ve kelle kesen bir teröristin görüntüsünü yayınlamak kadar ahlaki sorun barındırıyor." Aynı jüride fotoğarfın ödüllendirilmesi yönünde oy kullanan fotoğrafçı Mary F. Calvert ise "Biz fotoğrafçıyı ödüllendirdik, suçu değil" ifadelerini kullanmıştır (BBC Türkçe, 13.02.2017).

Bu çalışmada irdelenen ödüllü fotoğrafların geneli ölüm başta olmak üzere olumsuz yaşam koşullarını estetize etmiştir. Bu fotoğraflar, anlık gerçekliği sunmamaktadır. Daha ziyade olayı, olaydan sonraki süreçte görselleştirmiştir. Başka bir anlatımla, ele alınan fotoğrafların tümü pro-prodüksiyon içermektedir. Bunu belirtme nedenimiz, olay anında foto muhabirinin açı ayarlamaya zamanının olamayacağını ve böylesi durumlarda ortaya çıkacak sanatsal değeri yüksek basın fotoğrafları üzerinde etik tartışmaların daha ılımlı yürütülmesi gerektiğini vurgulama isteğimizdir.

Çalışmada ele aldığımız fotoğrafların genelinde şiddet görenin ya da ölenin yüceltilerek kutsallaştırıldığı ve failin ise gizlendiği dikkat çekmektedir. Bu tür bir görsel anlatı beraberinde, kuramsal kısımda da değindiğimiz gibi etik tartışmalar yaratmaktadır. Çünkü bu tür görüntüler sadece yayınlanmamıştır, aynı zamanda foto muhabirine de ödül, sembolik sermaye/güç kazandırmıştır. Böylece de iki kez (hem yayınlanması hem de ödüllendirilmesi) etik sorunun doğmasına neden olmuşlardır. Durumu, Pieta Heykeli (Tablo 1 Görsel 1) ile Contemporary Issues single kategorisinde 2005 yılında birincilik ödülü alan fotoğraf (Tablo 1 Görsel 2) üzerinden irdelediğimizde her iki eserde de maktülün açıkça ortada olduğunu, failin ise aşırı bir dolayımla verildiğini, başka bir ifadeyle gizlendiğini söyleyebiliriz.

Tablo 1: Pieta Heykeli (Görsel 1) ile WPP'nin 2005 yılında Contemporary Issues Singles kategorsinde ödüllendirdiği fotoğrafın (Görsel 2) karşılaştırması. 


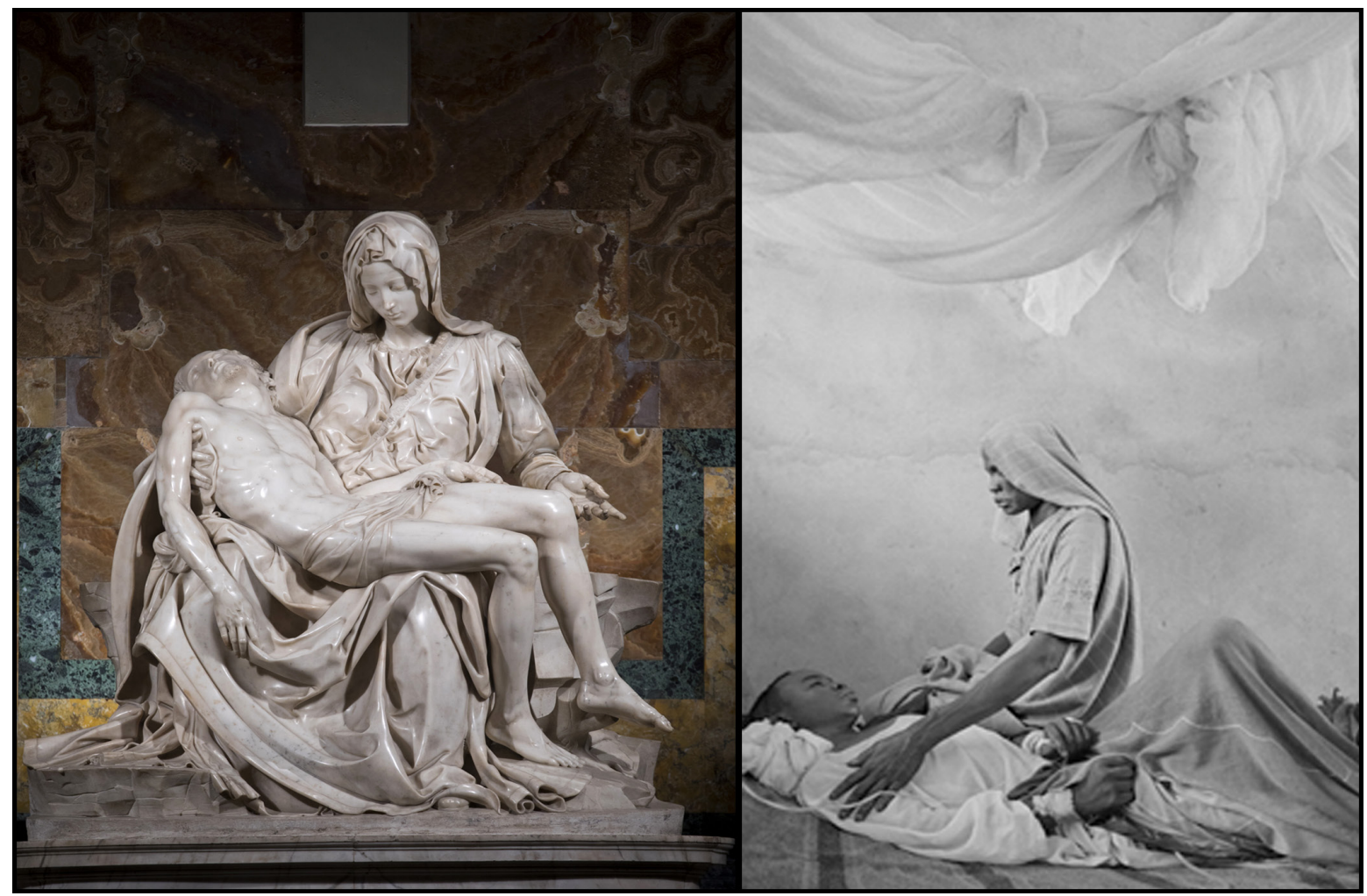

Görsel 1: La Pieta / Sanatçı: Michelangelo / Yil: 1499 / Yer: San Pietro Bazilikası - Vatikan / Açıklama: Pieta, Michelangelo Buonarroti'nun önemli eserlerinden birisidir. Görsel 1'deki heykel, Meryem'in oğlu İsa'ya duyduğu kederi görselleştiren Pieta heykellerinden ilkidir.

Görsel 2: Yil: 2005 / Foto-muhabiri: James Nachtwey / Kategori: Contemporary Issues Birincilik/Ülke: West Darfur: Açıklama: Etnik savaş yüzünden yerinden olan bir anne Batı Darfur' daki bir hastanede, Hepatit E ile mücadele eden oğlunun başında beklemektedir. İdiaya göre hükümetin de desteğiyle Arap milislerin, yerel siyahi Afrikalı nüfusa saldırmasıyla bölge yılın en büyük insani krizine şahitlik etmiştir. Saldırıda yaklaşık 150 bin insan hayatın kaybederken, 2 milyon insan ise bir etnik temizlik türü olarak da değerlendirilebilecek biçimde yerlerinden edilmiştir. Milisler, savaş suçuyla suçlanmış, ancak Birleşmiş Milletler, bunun bir soykırım eylemi olduğu şeklindeki iddiasından vazgeçmiştir. Güçlü uluslararası baskıların ardindan Sudan hükümeti, önde gelen Arap milislerini silahsılandırmayı kabul etmiştir.

Pieta heykelinde, anne oldukça genç tasvir edilmiştir. Fakat İsa'nın tahmini (Doğum MÖ 4 - MS 6 / Ölüm MS 30-33) 30-35 yaşları arasında öldüğü düşünülürse, bu yaşta bir evlada sahip bir annenin bu kadar genç olması mümkün değildir. Fransız şair ve yazar Christian Bobin (2012), güzelliği ve aklı görmek için yeni doğum yapmış kadına bakılmasını salık verir: "Eğer zekâ, düşüncenin o en narin çiçeği, resmedilmek istenseydi, hangisi olursa olsun genç bir annenin yüzü alınırdı." Eserde Meryem'in genç olarak tasvir edildiği genel bir kanıdır. Heykeldeki Meryem ve İsa'nın konumlanışına bakıldığında, bir annenin evladını bu şekilde kucağında tutabilmesi için, evladın ya yeni doğmuş/anne sütüyle besleniyor olması ya da yine çocuk olması ve annesinin sevgisine ve şefkatine fiziksel olarak mazhar olması gerekir. Bir annenin fiziksel olarak 30-35 yaşlarındaki evladını bu şekilde kucağında tutabilmesi pek olanaklı değildir. Bu, önemli bir noktadır. Çünkü bu heykel aslında doğum ya da çocukluk evresindeki anne-çocuk ilişkisini ölüm anıyla birleştirmiștir. Ölüme duyulan derin kederi, doğum ya da çocukluk dönemiyle görselleştirmiştir. Pieta aslında doğum ve ölüm imgesini aynı anda işleme başarısına sahip bir heykeldir. Burada sanatçı, sanatı aracılığıyla temsil ettiği anne-çocuk-doğum-ölüm olgusunu hem oldukça kederli biçimde hem de bu dünyanın geçiciliği üzerinden anlatır gibidir. İsa, annesi tarafından sanki hakiki mekânına uğurlanmak üzeredir. Meryem'in buradaki kederi, evladının ölümüne değil de ondan ayrıldığına gibidir. Heykelde derin bir keder hissedilmektedir ama yine de bir sakinlik ve dinginlik hâkimdir. 
$\mathrm{Bu}$, Kant'ın ifade ettiği yücelik duygusudur aslında. Heykel, bu haliyle fiziksel yokluğa duyulan kederi ve ruhani dünyaya dönüşün hakikiliğini işler görünmektedir. Bu duygular, heykeldeki Meryem' in duruşuyla, heykelin renk olarak tam beyaz değil de kırık beyaz olarak tasarlanmasıyla hissettirilmiştir. Ózetle ölüm anı, doğumun ya da çocukluğun bir başlangıç oluşuyla ya da ruhun ölümsüzlüğüyle kutsanmış/yüceltilmiştir.

2004 yılında ABD'li fotoğrafçı James Nachtwey tarafından West Darfur'da karelenen ve WPP'nin Contemporary Issues single kategorisinde 2005 yılında birincilik kazanan fotoğraf, Pieta heykelleriyle anlatı ve anlam açısından oldukça örtüşmektedir. Günümüzde fotoğraf teknolojisinin, renkli fotoğraf çekimine olanak tanımasına rağmen söz konusu fotoğraf siyah beyaz karelenmiştir. Fotoğraf karesinde bir anne ciddi bir hastalık (Hepatit E) taşıyan oğlunun başucunda beklemektedir. Fakat fotoğrafın teknik özellikleri (çerçeveleme, renk, objeler vb.), olayı öyle sunmuştur ki yaklaşan ölümün verdiği derin keder yine çocuğunun başında bekleyen ve ona fiziksel olarak temas eden bir anne ile anlatılmasına rağmen, fotoğraf çerçevesine dahil edilen üst taraftaki tüller (en azından fotoğraf teknik açıdan bunlara tül hissi vermiştir) bir bebek ya da çocuk yatağını -beşiği- anımsatmaktadır. Fotoğraf yine iki anlamlıdır. Temel anlam ölümdür, lakin yan anlam olarak yaşamın başlangıcı olan doğum ya da çocukluk dönemi hissettirilmiştir. Eco (2008: 22, 38; ayrıca bkz. 2016), bir sanat eserinde anlamın üç niyetin diyalektiği sonucunda kurulduğunu ifade eder. Sanatçının niyeti, sanat eserinin niyeti ve okuyucunun niyeti. Bu fotoğrafta sanatçı, belki doğum ya da bebeklik dönemine bir göndermede bulunmamış olabilir, lakin sanat yapıtı sanki böyle bir niyete bürünmüş gibidir. Bu eserin alımlayıcı olarak bizlere de hissettirdiği budur. Ruhani bir ortamda ölü̈m hissi, doğum ve bebeklik gibi yeni bir başlangıçla sentezlenmiş gibidir. Bu fotoğraf, sanatsal niteliği yüksek olan bir fotoğraftır. Bu fotoğrafçının kuşkusuz bir anlatım başarısıdır. Bu fotoğrafın anlamı oldukça derindir. Fakat anlattığı olaya ilişkin doğrudan ve açık bir fikir vermemektedir. Aslında fotoğraf Arap militanlarının saldırılarının yarattığı genel durumu işlemektedir. Oysa fotoğraf, görüntü olarak bu militanlara ya da saldırıya ya da mevcut duruma ilişkin bir anlatımı sahip değildir. Çünkü fotoğraf savaşın yarattığı bir sonuca odaklanmış ve durumu da bir tablo gibi sunmuştur. Kadın, çocuk, engeli, azınlık vb. dezavantajlı grupların ya da şiddet, ölüm vb. durumların medyada istismar nitelikli temsilleri oldukça tartışmalıdır. Bu nedenle foto-muhabirinin bu kadar sanatsal bir fotoğraf çekmesi olayı yerinden etmekte/bağlamından ayırmaktadır. Oysa haber medyasının görevi, mümkün olduğunca enforme edici bir içerikle okuyucuyu beslemektir, yönlendirmek değil.

Tablo 2: Pieta Heykeli (Görsel 3) ile WPP'nin 2005 y1lında General News Singles kategorisinde ödüllendirdiği fotoğrafın (Görsel 4) karşılaştırması. 


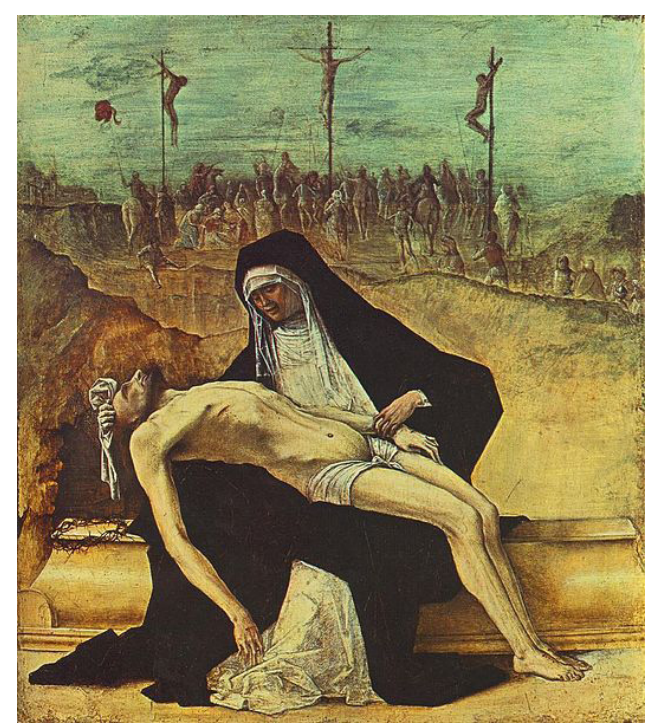

Görsel 3: Resim - Pieta (Predella of Stories of Christ) Yil: 1482-1486 / Sanatçı: Ercole de Roberti / Açıklama: Pieta, 14. yüzyıldan bu yana Batı Avrupa sanatında önemli bir figürdür. Bu örnek olağanüstü duygusal bir güç barındirmaktadır. Bakire Meryem, oğlunun cesedinin konulacağı lahitin kapă̆ına oturmaktadır, bu arada lahit sadece Meryem'in arkasinda görülmektedir. Mesih'in solgun cesedi, Meryem'in siyah peleriniyle kontrast oluşturacak biçimde tasvir edilmektedir (https://vads.ac.uk/large.php? uid = 243954\&sos=0)

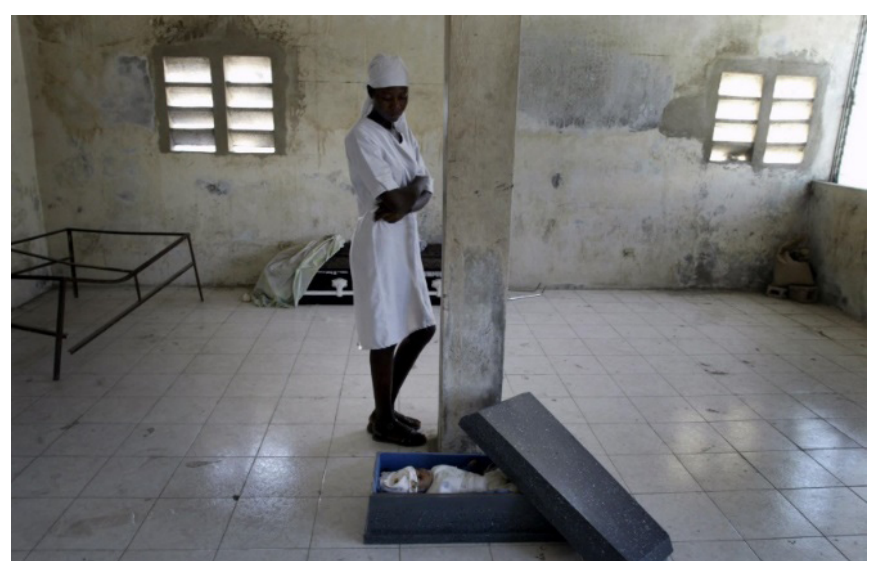

Görsel 4: Yil: 2005 / Foto-Muhabiri: Shaul Schwarz - İsrailli / Kategori: People in the News - Üçüncülük / Ülke: Haiti / Açıklama: Bir anne, hastanede derme çatma bir morgda ölü bebeğinin yanında durmaktadır. Başkan Jean-Bertrand Aristide' ye başkaldıran isyancilar, yılın başlarında kentin kontrolünü ele geçirdiğinden beri hastane kapalıdır. Bebek karışılık başlamadan kısa bir süre önce doğmuştur ve gerekli bakımları yapılmamıştır. Haiti'deki huzursuzluk, 2000'de tartışmal seçim sonuçlarnndan bu yana, Gonaïves'in belirli bir parlama noktası oldu ğu ve her iki tarafin da şiddet için birbirlerini suçladıklarından bu yana giderek artmıștır.

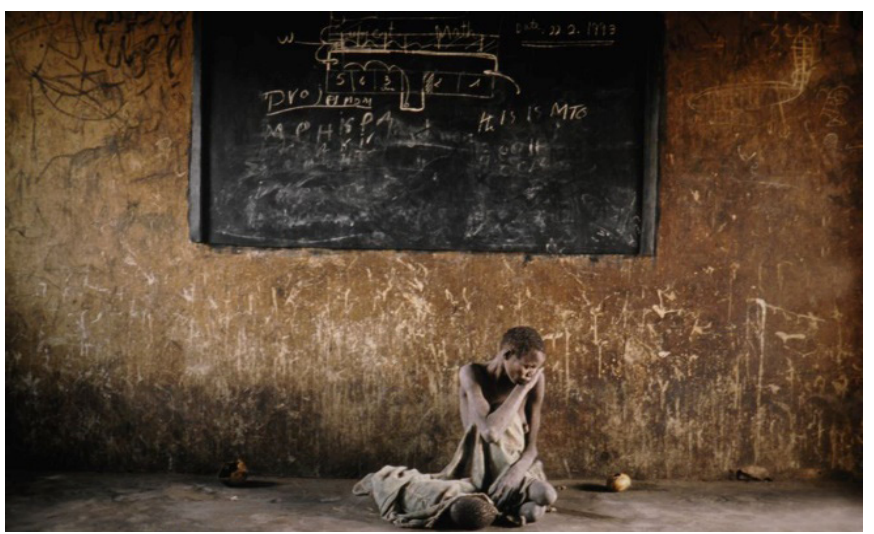

Görsel 5: Yil: 1994 /Foto-Muhabiri: Keith Bernstein İngiliz / Kategori: General News - Üçüncülük / Ülke: Sudan / Açıklama: Bir anne, yetersiz beslenmeden ölen çocuğunun yanında oturmaktadır. Uzun bir yürüyüş onlarn bu terk edilmiş okula getirir. Bu okul, iç savaş nedeniyle hasar görmemiş bölgedeki birkaç binadan birisidir. Yardım ajansları okulu acil beslenme merkezi olarak kullanmıștır.

Tablo 2'deki Görsel 4 ve 5 için de aynı yorumları yapmak mümkündür. Yukarıda değindiğimiz gibi Leppert, tarihteki en kutsal kurbanın İsa olduğunu, suçsuz yere cezalandırılan diğer bedenlerin tümünün, İsa'nın bir türevi şeklinde resmedildiğini dile getirmektedir. Aynı şey bugün basın fotoğrafçılığı için de kıșmen geçerlidir. Suçsuz yere ölen insanların basın fotoğrafları aracılığıyla temsili, çoğu kez İsa'nın ölümü gibi tasvir edilmektedir. Tablo 2'deki Görsel 4 ve 5 'te ölüm, anne-çocuk ilişkisi üzerinden kutsallaştırılmıştır. Ölümün geriye bıraktığ derin keder, kadınla tasvir edilmek istense de mekanın yoksulluğuyla ve hatta giyisilerin eskilğiyle/yıpranmışlı̆̆ıla da pekiştirilmiştir. Daha önce ifade ettiğimiz gibi, ölüm ancak yoksulluk üzerinden yüceltilebilir. Fotoğraflar, siyah, gri ve kahverengi gibi koyu tonlara sahiptir. Bu, durumun ciddiyetine bir vurgudur. Ölümün olduğu yerde, sadece insanlar değil mekanlar da sessizliğe bürünmelidir. Mekan, orada bir insanın öldüğünü hissettirecek kadar mütevazı olmalıdır. 
İsa'nın ölümüne dair hikayede, kadınlardan söz etilmektedir. İsa'nın, mezarında olmadığını fark edenler, birkaç gün sonra mezara baharat götüren kadınlardır. Gerek heykelde, freskte ve resimde olsun gerekse fotoğrafta olsun, ölümün yüceltilmesi ve beraberinde hakikatin üstünün örtülmesi, kadın, çocuk ve harabe mekan imgelerinin kullanılmasıyla sağlanmıştır. İki fotoğrafın teması da ölümdür. Tablo 2 Görsel 4, Ingiliz foto-muhabiri Keith Bernstein tarafından Sudan'da karelenmiş ve WPP General News kategorisinde üçüncülük almıştır. Fotoğraf, Sudan'daki açlığa dikkat çekmektedir. Tablo 2 Görsel 5 ise 2005 yılında İsrailli foto-muhabiri Shaul Schwarz tarafından Haiti' de çekilmiştir. Fotoğraf, siyasi karışıklığı temsil etmeye çalışmaktadır. Ancak ana temaları, fotoğraflar üzerinden doğrudan bulabilmek çok da olanaklı değildir.

Ölümün ya da şiddetin sanatsal aktarımına ilişkin bazı Rönesans dönemi resimleri ve güncel WPP ödüllü basın fotoğrafları dikkat çekici biçimde örtüşmektedir. Bu örtüşmeyi gösteren resim ve fotoğraflar kiyaslamalı olarak Tablo $3^{\prime}$ te sunulmuştur.

Tablo 3: Resim ile Fotoğraf arasındaki benzerliklere ilişkin kıyaslamalı görüntüler. Sol sütunda resim, sağ sütunda ise fotoğraflar ve açıklamaları yer almaktadır.

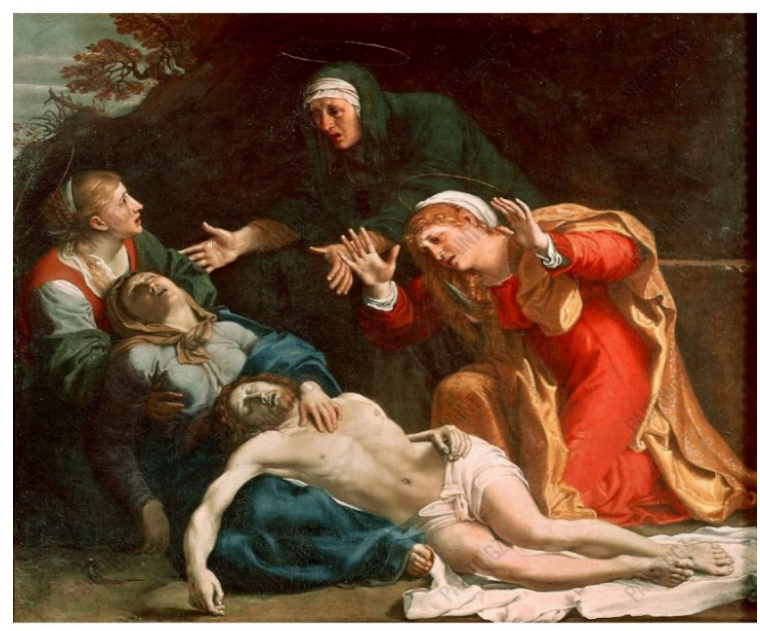

Görsel 6: Laminasyon - The Dead Christ Mourned (The Three Maries) / Yıl: 1604 / Sanatçı: Annibale Carracci / Açıklama: Bu, belki de Ulusal Galeri'nin Pietà koleksiyonundaki en dokunakl görüntüdür çarmıha gerilmesinin ardından ölü Mesih üzerindeki laminasyondur. Burada, Mesih'in salınmış cansız bedeni, annesi Meryem' in kucăğnda yatmaktadır. Açı içinde Mary Magdalene, dizlerini yana yatırmış, ellerini kaldırmıs ve feryatla ă̆zını açarak çığ lık atmaktadır. Arkasında koyu yeşil elbiseli yaşlı bir kadın, kilolu, genç bir kadin tarafindan desteklenen baygin bakireye doğru uzanmaktadır. Kompozisyon, güçlü kössegenler üzerine oturtulmuştur. Gözümüz resmin etrafina renk, bakış ve ifade ile yönelmektedir (The National Gallery, https://www.nationalgallery.org.uk/paintings/annibale-carracci-the-dead-christmourned-the-three-maries). 


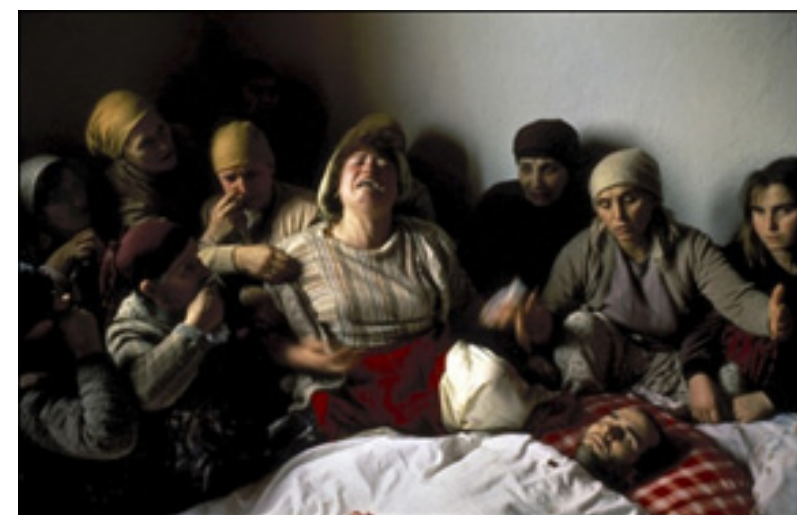

Görsel 7: Yıl: 1991 / Foto-Muhabiri: Georges Merillon - Fransız / Kategori: Photo of the Year / Ülke: Yugoslavya / Açıklama: Aile ve komşuları, Kosova'nın özerkliğini fesheden Yugoslavya hükümetine karşı düzenlenen bir protestoda hayatın kaybeden Elshani Nashim'in yasını tutmaktadır.

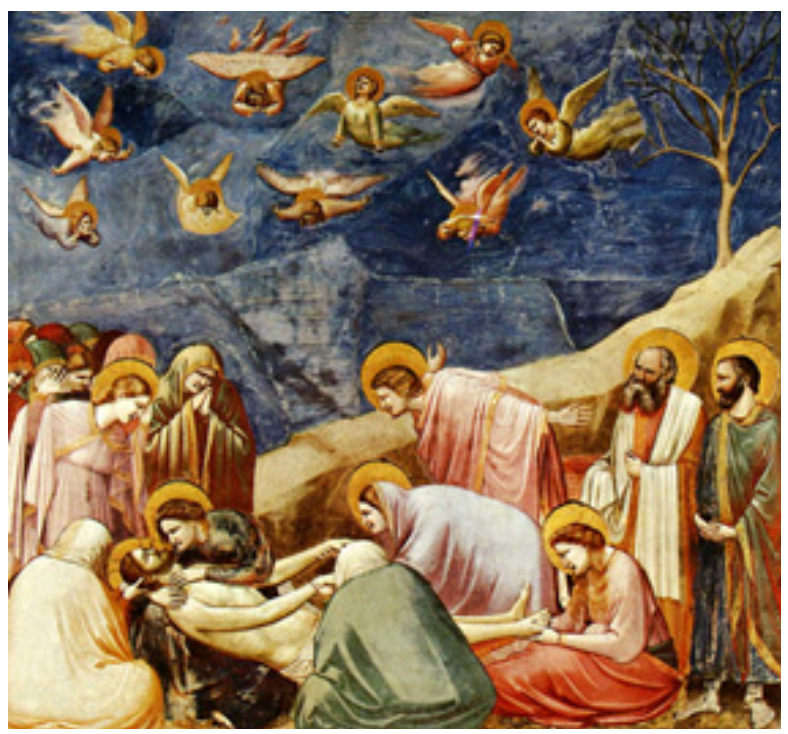

Görsel 8: Lamentation / Yil: 1304-1306 / Resssam: Giotto di Bondone / Yer: Scrovegni Şapeli, Padua. Açılama: Giotto'nun resminde, ön planda, İsa'nın bedeninde bir çember oluşturan ve zemine temas etmemesini șă̆layan ve görebildiğimiz beş figür vardır. Törensel (Hıristiyanlı̆̆a özgü) kıyafetli üç kadın figür, İsa'nin cesedini taşımaktadır. Diğer iki kişi bizden uzak durur gibidir. Resmin să̆ tarafinda orta zeminde üç adam vardır. Sonunda, resmin solunda ve ortasında, yas tutan kadınların kalabalığı yer almaktadır. Kayalık bir dă̆ sırtı kompozisyonu, bakışımızı Meryem ve İsa'ya yönlendirmektedir. Arka plandaki ă̆aç muhtemelen İnsan Düşüşünden beri çorak olan ve bize ilk günahı hatırlatan iyi ve kötü bilginin agacıdır. Gökyüzünde on bir melek vardır. Aslında, bu resimde, Cennet ve Dünya'nın yasta bir araya geldiğini göstermektedir (Thirty-Two Minutes, https://32minutes.wordpress.com/2012/04/06/ looking-at-giottos-the-lamentation/). 


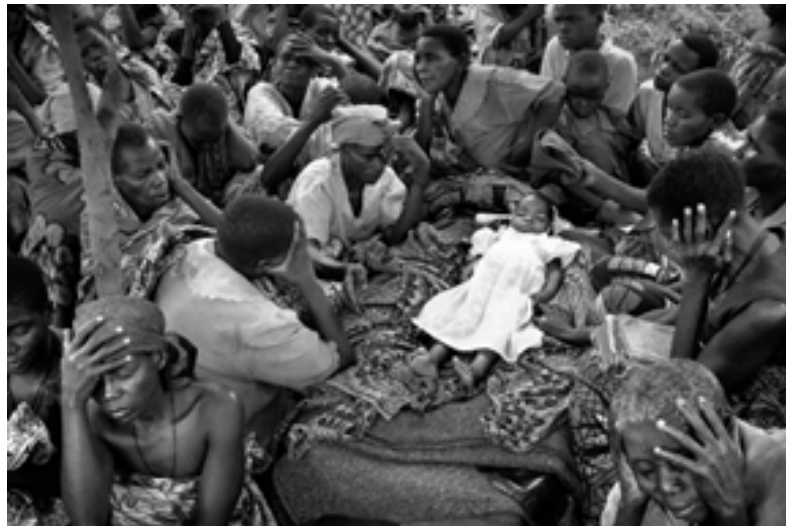

Görsel 9: Yil: 2006 / Foto-Muhabiri: Sven Torfinn - Hollandah / Kategori: People in the News - Birincilik / Ülke: Demokratik Kongo Cumhuriyeti / Açıklama: Yaslı akrabalar, Mart ayında dizanteri nedeniyle ölen 5 yaşındaki Vani Vamuliya'nın cesedinin başında yas tutmaktadırlar. Vani'nin son günleri, Tche'deki ülke içinde yerlerinden edilmiş kişiler için oluşturulan bir kampta geçmiştir. Demokratik Kongo Cumhuriyeti'nde, II. Dünya Savaşı'ndan bu yana en kanlı çatışmalardan birinde, yaklaşık 4 milyon kişinin 6 yıl süren şiddete maruz kaldığı düşünülmektedir. Angola, Namibya ve Zimbabve'nin desteklediği hükümet güçleri, Uganda ve Ruanda tarafindan desteklenen isyancılara mücadele eder. Kayıpların çoğu kadın ve çocuktur ve çoğu açlıktan ya da hastalıktan ölmüştür. 2003 yılında bir barış anlaşması imzalanmasına rağmen, özellikle ülkenin doğusunda milis şiddeti devam eder. Vani'nin ölümünden önceki haftalarda, Tche'deki kampa yaklaşık 13.000 kişi sığınmıştır.

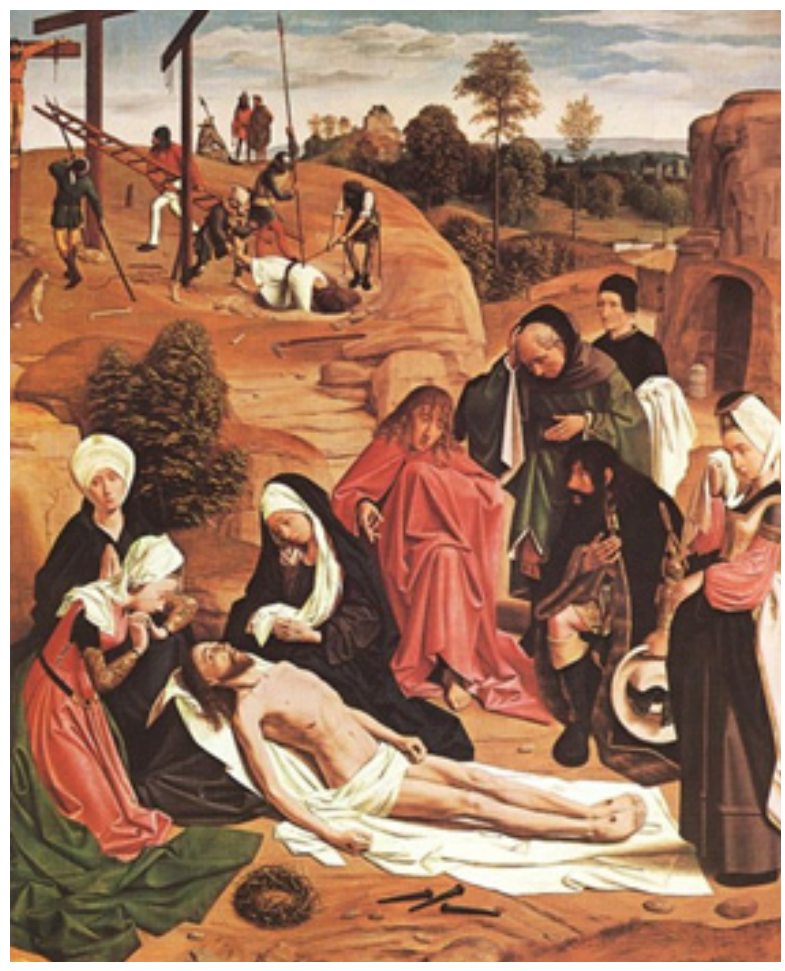

Görsel 10: The Lamentation of Christ/Yıl: 1460-1465/Sanatçı: Geertgen tot Sint Jans / Açıklama: Ölü Mesih'e, annesi Mary ve diğer iki kadın ağıt yakmaktadır. Muhtemelen seyirciler arasında, bedeni haçtan indirmeye izin alan adam Nicodemus'tur. Kırmızı cüppeli adam Evanjelist John olabilir. Vücudun yanında yer alan objeler, dikanli taç ve demir çivilerdir. 


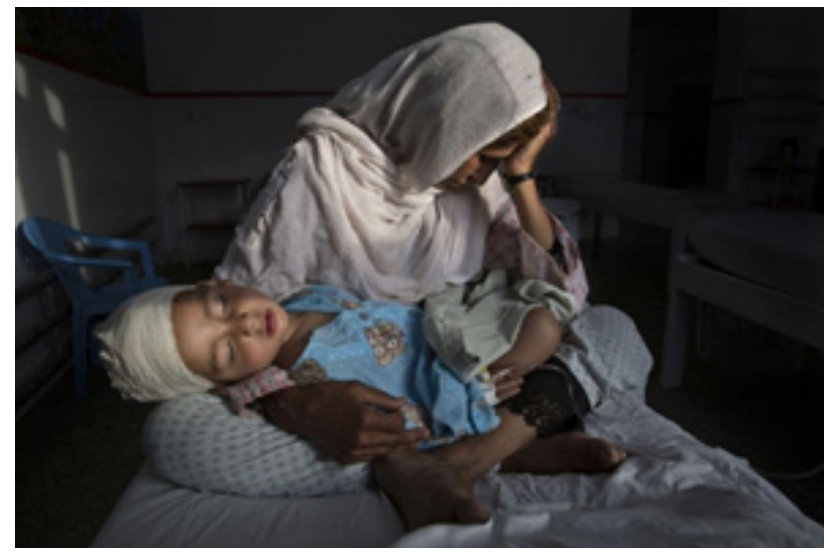

Görsel 11: Yal: 2017 / Foto-Muhabiri: Paula Bronstein - Amerikah / Kategori: Daily Life / Birincilik / Ülke: Afganistan / Açıklama: Najiba, Mart ayında Afganistan'ın Kabil kentindeki kız kardeşinin de ölümüne neden olan bir bomba patlaması sonucunda yaralanan yeğeni Shabir'i (2) kucă̆ında tutmaktadır. Bomba, Kabil'in nispeten huzurlu bir bölümünde, Shabir'in annesi çocukları okula götürürken patlamıştır. 2001-2014 Afgan Savaşı resmen sona ermiş olsa da, ülkede, baş isyancılar ile Afgan ordusunu destekleyen ABD ve diğer uluslararası güçlerle çatışma devam etmiştir. Mücadele, intihar ve sivil yaşamı dengesizleştirmeye yönelik saldırılar hedef alan bir artışla köylere ve şehirlere sıçramıştır. Birleşmiş Milletlere göre, çocuk kayıpları 2016 yılında yüzde 24 artmış, 2.589 kişi yaralanmış ve 923 kişi ise ölmüştür.

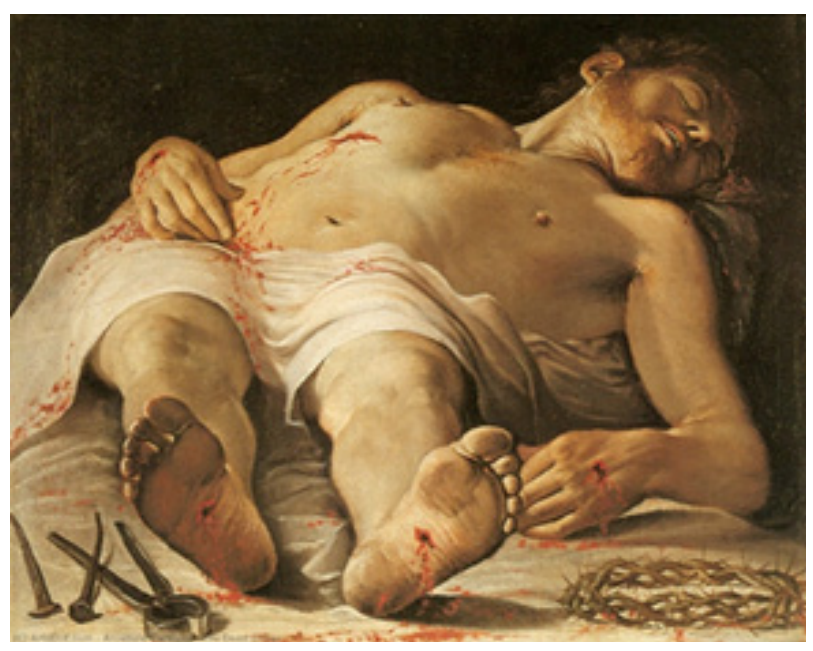

Görsel 12: Resim - Corpse of Christ / Sanatçı: Annibale Carracci / Yıl : 1583-1585 / Açıklama: Annibale Carracc'nin Ölmüș İsa'sl, çarmıhtan henüz indirilmiş ve defnedilmek üzere olan bedeni temsil ediyor. Kompozisyona perspektif verme işinde ustalı̆̆n sergilendiği resim, dikkatlerimizi imgeye ve dolayısıyla da genç ressamın büyük teknik becerilerine çeken çarpıcı bir görsel söylemi yansitıyor. Bedenin sakatlanmasın görüyoruz burada. Görüş açısı sayesinde İsa'nın bedeninin birçok yerinde delindiğini ve bunun için kullanılan başlıca aletleri görebiliyoruz: Dikenli tel ve özellikle de kamayı andıran çiviler; çarpık çivilerin düz başları, görünmeyen çekiç darbelerinin şiddetini yansıtıyor. Önde solda, İsa'nın bacağına paralel duran çivilerin sökülmesinde kullanılan -sökülürken eğrilmiş çiviler-bir kerpeten var. Hâlbuki Kutsal Kitap'ta kerpetenden söz edilmiyor. (...) Isa'nın bedeni alay edilecek bir nesne değil, acmacak bir nesne haline getiriliyor. Başka bir ifadeyle, İsa'nın işkence görmüş hali işkencecilere karşı bir "tez" geliştiriyor (Leppert, 2017: 168). 


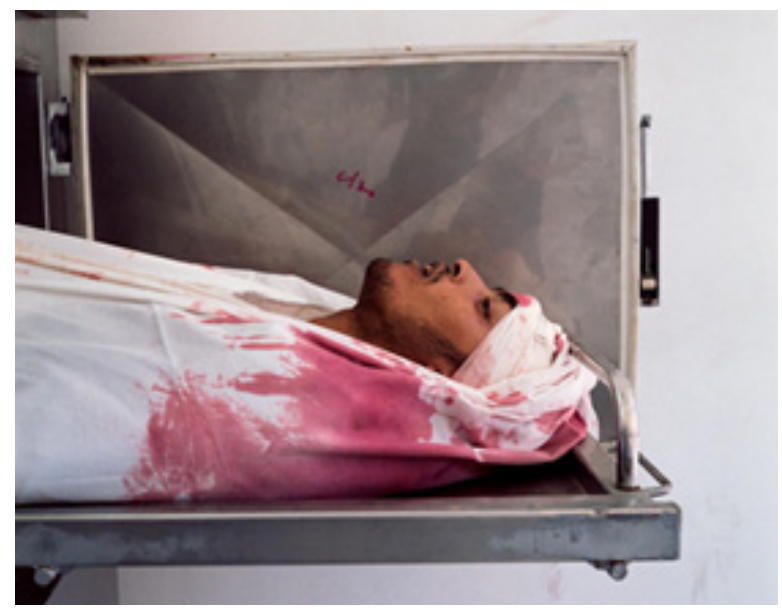

Görsel 13: Yal: 2005 / Foto-Muhabiri: Kristen Ashburn- Amerikalı / Kategori: People in the News / Birincilik / Ülke: İsrail / Açıklama: Mohammed Jaber Daffallah (22), yatak odasınının penceresinden dışarı bakarken İsrail ordusuna ait bir keskin nişancı tarafindan başına isabet eden bir kurşunla vurulmuştur. Filistinli militanlarm Israil yakınlarındaki Sderot yerleşim bölgesini attıkları iki roketle yakmaları ve iki insanı öldürmeleri sonrası İsrail güçleri bölgeye girmiş ve bölgeyi kuşatmıştır. İsraillilerin aktardığına göre yerel çiftlikler ve bahçeler militanları gizlemek için kullanılmıştır.

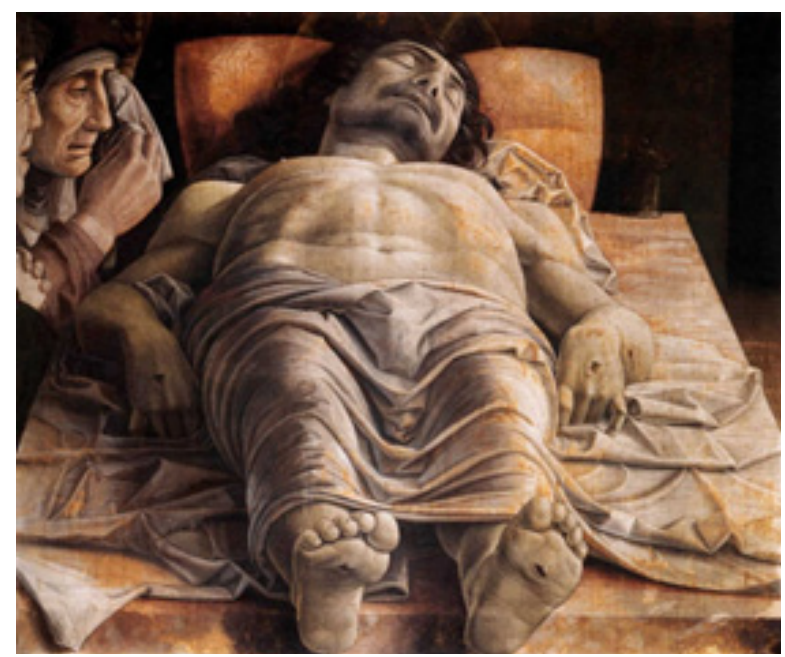

Görsel 14: Resim - Lamentation of Christ / Yıl: 1470-1474 / Sanatçı: Andrea Mantegna / Yer: Pinacoteca di Brera, Milano / Açıklama: Mermer bir levha üzerinde sırt üstü Mesih'in gövdesini gösterir. Bakire Meryem, Aziz John ve ölüm için ağlayan Bakire Meryem'in hemen sol üst köşesindeki biri tarafindan izlenmektedir. 


\section{Sonuç Yerine}

Görselleştirme, tarihten günümüze her dönemde olayı betimlemede önemli bir yöntem olarak kullanılmıştır. Bu yöntem, olayın anlatımını kuvvetlendirmede üstüne düșeni her zaman yerine getirebilmiştir. Ama gerçeği, tüm açılığıyla ortaya koymada bekleneni yerine getirip getirmediği, yukarıda da değinildiği gibi, tartışmalıdır. Yaşamını sanatla kazanan insanlar, yani sanatçilar, üretimleriyle toplumsal süreçleri olumlu ya da olumsuz anlamda tarihin her döneminde yönlendirmişlerdir. 17. yüzyıldan itibaren basın, 19.yüzyılda ise önce fotoğraf sonrasinda ise onun temelleri üzerine gelişen sinema ile 20. yüzyılın ilk yarısında televizyon bu sürece dâhil olmus ve yönlendirme hız kazanmıștır. Çalışmada ele alınan fotoğrafların tümü, Hıristiyan-Batılı bir bilincin dışavurumudur. Batı, bilhassa dini değerler olmak üzere kendi değerlerini yaymak için yüzlerce yıllık bir uğraş -kuşkusuz bu sadece Batı toplumları için değil, tüm toplumlar için geçerlidir- sergilemiștir. Bu düșünceyi yaymak ve toplumlara kabul ettirmek için birtakım tekniklere başvurmuştur. Çalışmanın kuramsal kısmında değindiğimiz gibi, Batı birçok kurum gibi sanatı da zaman zaman ideoloji-kültürel değerleri yayma aracı olarak kullanmıştır.

Denetim altına alınması gereken büyük kitleler mevcuttur. Sistemin, sistematik bir şekilde işleyebilmesi için öncelikle kitlelerin bunu kabullenmesi gerekmektedir. Bu da ancak, aklın rasyonel yanına değil, hazcı-duygusal irrasyonel yanına seslenerek sağlanabileceği anlaşıldığından, Batı, tüm kurumlarıyla aklın rasyonelliğinden ziyade duygusallığınıirrasyonelliğini ön plana çıkartmıştır. Din, dil, ulus, etnik, coğrafi yakınlık, kültürel ortaklık gibi yapay-irrasyonel söylemleri sanat üzerinden de topluma aktarmıştır. İnsanlık, sanat üzerinden kendi insan olma hakikatininin yanı sıra büyük ideolojileri de öğrenmiştir. Batı sanatı, özellikle kilise himayesinde şekillenen Avrupa-merkezci sanat, olayların hakikatini göstermeyi ya da olaylara rasyonel yaklaşım sergileyebilecek aklın iyi yanı üzerine odaklanmaktan daha çok, aklın kötü yanı üzerinden kitleleri sisteme dâhil etmiştir. Zaman içerisinde gelişen yeni sanat dalları ve basın/medya gibi kitle iletissim sistemleri de sözü edilen sürece hizmet eder olmuştur. Kracauer'in ( 2015, s.137), geleneksel sanatların kitleleri etkileme ve yönlendirme gücünün zayıfladığını ve bu nedenle bu görevin 19. yüzyıldan itibaren fotoğraf ve film gibi yeni iletişim/sanat araçlarıyla sağlanabileceğinin kavrandığını belirtmesi çok anlamlıdır.

Çalışmada ele alınan basın fotoğrafları küresel düzlemdeki güç mücadelelerinin bir ürünüdür. Teknolojik Kuzey, teknolojiden yoksun Güney, gelişmiş Batı, gelişmemiş Doğu ve bu ayrımları yaratan siyasi, iktisadi ve kültürel güç mücadelelerini normal bir bilinç düzeyinde sorgulatacak nitelikte değildir. Haber medyasının temel hareket noktası, haberin, konuyu, her kesimden herkesin rahatlıkla anlayabileceği biçimde işlemesi yönündedir. Böylesi sanatsal fotoğraflar, kitle düzeyinde değil de entelektüel düzeyde durumu sorgulamalara açabilir. Lakin burada kitlenin de durumu anlaması gerekmektedir. Kitlelerin bu fotoğraflardan anlayacağı, büyük ölçüde insanların öldüğü ve mağdur olduğudur. Verecekleri tepki ise empati yoluyla duygulanımdır/üzülmedir; çünkü insanlar ölmüş ya da hastadır. Ama kimlerin mağdur ettiği kitleler düzeyinde genelde kayıptır. Bu çalışmada incelenen fotoğraflar, sanatsaldır ve mesajını büyük ölçüde dolaylı ama genel olarak büyük ölçekli faili göstermeden mağdur üzerinden kurgulamıştır.

Sanatçının, iletisini, sanatsal biçimlere büründürerek sunması doğal bir durumdur. Sanatçı, ele aldığı konuyu kendi beğeni yargısı doğrultusunda anlatarak maddi ve manevi anlamda varlığını sürdürmektedir. Bu, onun işidir. Fakat medya çalışanı, çalışma özelinde konuşacak olursak, foto-muhabirinin işini yaparken, konuyu -ki sanat eserine oranla gerçeğe oldukça yakın olmak, olayı olabildiğince aslına uygun bir biçimde ve tüm gerçekliğiyle sunmak zorundadır-, işlerken haber üretim sürecinin genel kabullerini dikkate almalıdır. Epiktetos, Düsünceler ve Sohbetler eserinde, erdemi, elinde olanı yapmak ve gerisi için metin ve sakin olmak gerektiğini söyler. İnsan, üzerine düşeni yapmakla görevlidir. Fazlasını değil (Epiktetos, 1989: 77):

Deniz yolculuğuna çıkmağa mecburum. O halde ne yapmalıyım? Gemiyi, kaptanı, tayfaları, mevsimi, günü, rüzgârı iyi seçmek, işte elimde olan şeyler. Denize açlır açılmaz müthiş bir Artma [fırtına yn.] kopar, bu benim düşüneceğim bir iş değildir, kaptanın vazifesidir. Gemi batıyor, ne yapmalıyım? Elimde olanı yaparım, bağırıp çă̆ırmam, kendi kendimi yemem, Biliyorum ki her doğan ölür, bu umumî kanundur. O halde ölmem lâzımdır. Ben ebediyet değilim. Ben bir insanım; saat günün bir parçası olduğu gibi ben de bütünün bir parçasıyım. Saat gelir ve geçer. Ben gelir ve geçerim.

Foto-muhabirinin bir medya çalışanı olmasından dolayı takip edeceği ilkeler, haber üretim sürecinde gözönüne alınması gereken etik ilkeler olmalıdır. Eğer bir tercih söz konusu olacaksa bu sanatsal bir görselleştirme-simgeselleştirmeden yana değil, gerçekten yana 
olmalıdır. Çünkü her tercihin sonucu, o tercihten açılan pencereyle olayı algılayanları da kendi tahakkümüne çekmektedir. Medya diliyle konuşacak olursak, bu bir manipülasyondur. Sadece medyada değil tüm alanlarda her tercih, birtakım şeyleri içerimlerken birtakım şeyleri de dişlamakta, gözlerden ve düşüncelerden iraklaştırmaktadır. Özetle çalışmada incelediğimiz fotoğraflar, olayı maktul üzerinden kurgulayarak özneyi, diğer bir anlatımla büyük siyasi-kültürel ideolojileri ve amaçlarını gizlemekte, görünmez kılmaktadır. Herkes İsa'nın nasıl öldüğünü/öldürüldüğünü bilir. Ama İsa'yı kimin öldürdüğünü herkesin aynı oranda bildiğini söylemek mümkün değildir.

Son olarak foto muhabirlerinin bu tür fotoğraflarla kazançlarının ne olduğuna göz atmak gerekmektedir. Bu fotoğraflar, genel olarak sanatsal niteliğge sahiptirler. Kendilerini beğendirecek niteliktedirler. Ki zaten WPP, bu fotoğrafları anlatım ve görüntü gücü üzerinden ödüllendirmektedir. Foto-muhabiri, ödüllendirme yoluyla mesleğinde doruk noktasına yükselmektedir. Bourdieu'nun (bkz. 1986; 2005) dilinden konuşacak olursak, foto-muhabiri simgesel olarak güçlü bir pozisyona erişmektedir. Simgesel sermaye, beraberinde iktisadi sermayeyi, kültürel sermayeyi ve sosyal sermayeyi de getirmektedir. Şöyle ki, birinin ölümü, birinin tüm sermaye türlerinde başarılı olmasının nedeni olabilmektedir. Bu durumda çekilen fotoğraflar güzel midir? Kant, Yargı Gücünün Eleştiri yapıtında, içinde çıkar olan hiçbir şeyin güzel olamayacağını söylemektedir. "Herkes kabul etmelidir ki, güzellik üzerine içinde en küçük bir çıkarın karıştığı yargı çok 'yanlı' bir yargıdır ve bir arı yargı beğenisi değildir." (Kant, 2016: 40). Yani güzellik ve çıkar ilişkisi, ya da güzellik üzerinden çıar ilişkisi oldukça tartışmalıdır. Foto muhabirleri işlerini icra ederken, bu durumu göz önünde bulundurmalıdırlar.

Bu tür fotoğrafların üretilmesinde tek sorumluların foto muhabirleri olmadığını, onlara bu türden bir başarı ölçütü yükleyen medya kuruluşlarının da büyük payının olduğunu belirtmekte fayda vardır. Bu fotoğraflara, sadece foto muhabirleri eksenli değil, aynı zamanda çalıştıkları kuruluşların yapıları ya da genel olarak medya alanının mevcut-liberal mantığı bağlamında da yaklaşılması gerektiğinin farkında olduğumuzu belirtmemiz gerekmektedir.

Sonuç olarak fotoğraf ve fotoğrafın temelini oluşturduğu sinema, anı kaydetme, sabitleme, saklama işlevleri ve görüntünün gücü sayesinde kitleleri manipüle edebilmekte ve geleneksel görsel sanatlarla kıyaslandığında günümüz koşullarında çok daha kitlesel ve hatta evrensel düzeyde etkiler yaratabilmektedir.

\section{Kaynaklar}

Alankuş, S. (2007). Neden Kadın Odaklı Habercilik. Kadın. Sevda Alankuş (der.). IPS İletişim Vakf1. İstanbul: 25-66.

Aristoteles. (2018). Nikomakhos'a Etik, Saffet Babür (çev.), BilgeSu Yayıncılık, 8. Baskı. Ankara.

Baran, A. G., Sarıtaş, C. T., \& Kütük, B. Ş. (2017). Medyada kadına yönelik şiddet haberlerinin içerik ve sunum açısından analizi: Beyazgazete. com Örneği. Sosyoloji Konferanslari, (55), 107.

Berger, J. (2006). Görme Biçimleri, Yurdanur Salman (çev.), Metis Yayınları, 20. Baskı, İstanbul. Bolla, P. (2012). Sanat ve Estetik, Kubilay Koş (çev.), Ayrıntı Yayınları, 2. Baskı, İstanbul.

Bourdieu, P. (1986). The forms of Capital. Handbook of theory and research for the sociology of education, J. Richardson (Ed.). Greenwood Press, New York, USA: 241-258.

Bourdieu, P. (1991). Language and Symbolic Power, Gino Raymond and Matthew Adamson (Trans.), Polity Press, Cambridge, UK.

Bourdieu, P. (1998a). On Television, Priscilla Parkhurst Ferguson (çev.), The New Press, New York, USA.

Bourdieu, P. (2005). The political field, the social science field, and the joumalistic field. In R. Benson \& E. Neveu (Eds.). Bourdieu and the journalistic field. Polity Press, Cambridge, UK: 2947.

Bourdieu, P. (2006). Sanatın Kuralları, Necmettin Kamil Sevil (çev.). Yapı Kredi Yayınları, Istanbul.

Butler, J. (2011). Gender trouble: Feminism and the subversion of identity. Routledge.

Dursun, Ç. (2010). Kadına Yönelik Şiddet Karşısında Haber Etiği. Fe Dergi, 2 (1), 19-32. 
Eco, U. (2008). Yorum ve Aşırı Yorum, Tolga Esmer (çev.), Can Yayınları, 3. Baskı. İstanbul. Eco, U. (2016). Açık Yapıt, Kemal Atakay (çev.), Can Yayınları, 4. Baskı. İstanbul.

Epiktetos, (1989). Düşünceler ve Sohbetler (Batı Klasikleri). Burhan Toprak (çev.), Milli Eğitim Bakanlığı Yayınları, İstanbul.

Atman, R. (2018). Film Türüne Semantik/Sentaktik Bir Yaklaşım, Onur Dursun (çev.). Edebiyatta, Sinemada, Televizyonda Tür Kuramı/Temel Metinler, (Ed.) Jale Özata Dirlikyapan, Doğu Batı Yayınları, Ankara, ss.1, 2018

Rotha, P. (1995). Belgesel Sinema. Çev. İbrahim Şener. İstanbul: Sistem Yayıncılık.

Demirel, G. (2015). Fotoğrafın Manipülasyon ve Gündem Saptama Gücü. International Journal of Social Sciences and Education Research. 1(2): 758-769.

Erbalaban Gürbüz, Ö. N. (2018). Yusuf ile Kenan Filminde Suça İtilmiş Çocuklara Dair Toplumsal Göstergelerin Çözümlenmesi. Uluslararası Sosyal Araştırmalar Dergisi , vol.11: 345351.

Erbalaban Gürbüz. Ö. N. (2016). Korkuyorum Anne'de Hegemonik Erkekliğin Yapı Sökümü. Ankara Üniversitesi İlef Dergisi. 3(2): 125-142.

Freud, S. (2015). Kitle Psikolojisi, Kamuran Şipal (çev.), Say Yayınları, İstanbul.

Hegel, G. W. F. (1986). Seçilmiş Parçalar, Nejat Bozkurt (çev. ve der.), Remzi Kitabevi, İstanbul.

Hegel, G. W. F. (1994). Estetik, Güzel Sanatlar Üzerine Dersler (Cilt I) (T. Altuğ, H. Hünler, Çev.). İstanbul: Payel Yayınları.

Hegel, G. W. F. (2003). Tarihte Akıl, Önay Sözer (çev.), Kabalcı Yayınları, İstanbul.

Kant, I. (2016). Yargı Yetisinin Eleştirisi, Aziz Yardımlı (çev.), İdea Yayınları. 3. Baskı, İstanbul.

Kant, I. (2017). Güzellik ve Yücelik Duyguları Üzerine Gözlemler, Ahmet Fethi (çev.) Hil Yayın,

2. Bask1, İstanbul.

Kepplinger, H. M., \& Weißbecker, H. (1991). Negativität als Nachrichtenideologie. Publizistik, 36(3), 330-342.

Kojeve, A. (2015). Hegel Felsefesine Giriş, Selahattin Hilav (çev.). Yapı Kredi Yayınları, 5. Baskı, İstanbul.

Köker, L. (2007). Hukuk Reformları Sürecinde Türkiye' nin İnsan Hakları Sorunu: Bir Değerlendirme Çerçevesi. İçinde: S. Alankuş (Der.), Kadın Odakı Habercilik, Bi்A, İstanbul: IPS İletişim Vakf1 Yayınları, 51-79.

Leppert, R. (2017). Sanatta Anlamın Görüntüsü / İmgelerin Toplumsal İşlevi, İsmail Türkmen (çev.), Ayrıntı Yayınları, 3. Baskı, İstanbul.

McGregor, J. (2002, July). “Restating news values: Contemporary criteria for selecting the news." In Refereed articles from the Proceedings of the ANZCA 2002 Conference, Coolangatta. Communication: Reconstructed for the 21st Century.

Nietzsche, F. (2017). Ahlakın Soykütüğü Üzerine, Ahmet İnam (çev.). Say Yayınları. İstanbul. Östgaard, E. (1965). Factors influencing the flow of news. Journal of Peace Research, 2(1), 3963.

Platon. (2016). Diyaloglar, Tacettin Ünal (çev.), Remzi Kitabevi, 3. Bask1. İstanbul.

Platon. (2017). Devlet, Sebahattin Eyüboğlu - M. Ali Cimcoz (çev.), İşbankası Yayınları, 33. Bask1, İstanbul.

Sancar, S. (2014). Türk modernleşmesinin cinsiyeti: erkekler devlet, kadınlar aile kurar. İletişim Yayınları.

Shiner, L. (2004). Sanatın İcadı, İsmail Türkmen, (çev.), Ayrıntı Yayınları, 5. Baskı, İstanbul. TGC, (2016). Kadın ve Medya / Toplumsal Cinsiyet Eşitlikçi Haber Klavuzu, İstanbul: TGC Akademi.

Uzun Aydın, D. (2017). Benzer ve Farklı Yönleriyle Resim ve Sinema İlişkisi. The Journal of Academic Social Science Studies, 56, 393-408. 
Wilkins, K. G. (1995). Middle Eastern women in Western eyes: A study of US press photographs of Middle Eastern women. The US media and the Middle East: Image and perception, Yahya R. Kamalipour (Ed.), Greenwood Publishing Group, USA: 50-61. Williams, R. (1961). The Long Revolution, Penguen Books, UK.

Bolla, P. (2012). Sanat ve Estetik. Çev. Kubilay Koş. İstanbul: Ayrıntı Yayınları. 2. Baskı.

Yıldız F., \& Aydoğmuş Ö. Ö. (2018). Childhood Ideology in The Early Turkish Republican Era. Journal of Politics and Law, 11, 82-97.

Zizek, S. (2011a). Olumsuzla Oyalanma, Hakan Gür (çev.), İmge Kitapevi, İstanbul.

Zizek, S. (2011b). Kırılgan Temas, Bülent Somay, Tuncay Birkan (Haz.), Tuncay Birkan (çev.), Metis Yayınlar1, 3. Bask1, İstanbul.

Shin, B., \& Namkung, G. (2008). Films and cultural hegemony: American hegemony

"Outside" and "Inside" the "007". Movie Series. Asian Perspective, 32(2), 115-143.

\section{Online Kaynaklar}

VADS (The Online Resourse for Visual Art), https://vads.ac.uk/large. php?uid $=243954 \&$ sos $=0$.

The National Gallery, Erişim Tarihi: 25.10.2019, https://www.nationalgallery.org.uk/ paintings/annibale-carracci-the-dead-christ-mourned-the-three-maries)

Thirty-Two Minutes, 6.4.2012, Erişim Tarihi: 27.10.2019. https://32minutes.wordpress. com/2012/04/06/looking-at-giottos-the-lamentation/.

Smyth, Diane. 2018. “Q\&A: Patrick Brown, World Press Photo of the Year nominee”, British Journal of Photography. Erişim Tarihi: 20.10.2019, Söyleşi için bkz. https://www.bjp-online. com/2018/02/qa-patrick-brown-world-press-photo-of-the-year-nominee/.

World Press Photo, Erişim Tarihi: 09.09.2019, https://www.worldpressphoto.org/ collection/photo $\% 20$ contest.

Çakır, A. VoA, 27.11.2017. “Ödüllü Foto Muhabiri Özbilici: 'Tek Düşüncem İşimi Yapmaktı'”, Erişim Tarihi: 27.04.2020, https:// www.amerikaninsesi.com/a/odullu-foto-muhabiri-ozbilici-world-pressphoto-odulu/4138887.html

Safarov, F. Sputnik, 13.02.2017, Erişim Tarihi: 26 Nisan 2020, https://tr.sputniknews.com/ haberler/201702131027191190-andrey-karlov-world-press-photo-burhan-ozbilici/

Franklin, Guardian, 25.11.2020, Erişim Tarihi: 28.04.2020, https://www.theguardian.com/ commentisfree/2017/feb/13/world-press-photo-year-turkey-russian-assassination

BBC Türkçe, 13.02.2017, ‘Büyükelçi Karlov suikastı: Yılın Fotoğrafı ödülü jüriyi böldü', Erişim Tarihi; 01 May1s 2020, https://www.bbc.com/turkce/haberler-dunya-38955110

TGC, 2019. 'Türkiye Gazetecileri Hak ve Sorumluluk Bildirgesi', Erişim Tarihi: 02.05.2020, https://www. tgc.org.tr/bildirgeler/t\%C3\%BCrkiye-gazetecilik-hak-ve-sorumluluk-bildirgesi.html 